No $2003-12$

September

MARKET ACCESS LIBERALISATION IN THE DOHA ROUND: SCENARIOS AND ASSESSMENT

Lionel Fontagné, Jean-Louis Guérin \& Sébastien Jean 
MARKET ACCESS LIBERALISATION IN THE DOHA ROUND:

SCENARIOS AND ASSESSMENT

Lionel Fontagné, Jean-Louis Guérin \& Sébastien Jean

No $2003-12$

September 
TABLE OF CONTENTS

SUMMARY .................................................................................................................................

ABSTRACT .........................................................................................................................................

RÉSUMÉ.........................................................................................................

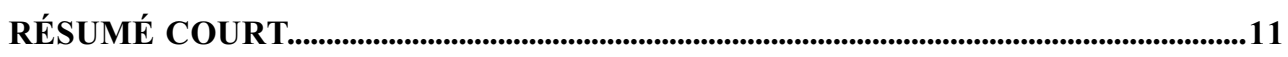

1. INTRODUCTION......................................................................................................................13

2. AN OVERVIEW OF CURRENT PROTECTION..........................................................17

3. THE MODEL MIRAGE....................................................................................................22

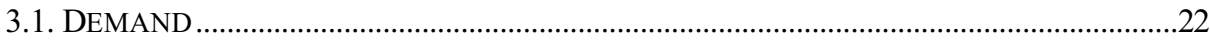

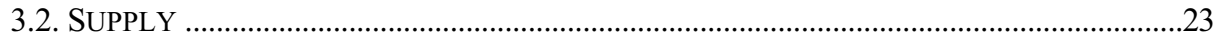

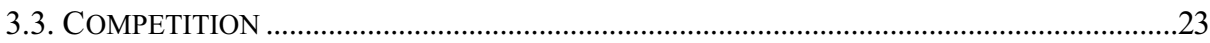

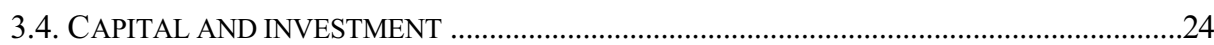

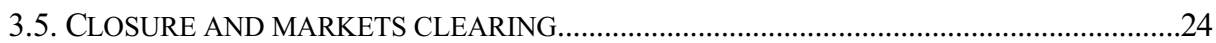

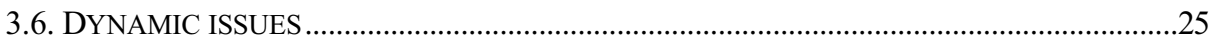

4. SCENARIOS .........................................................................................................25

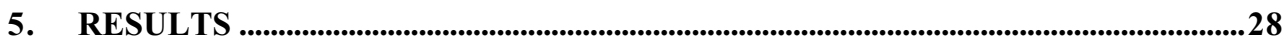

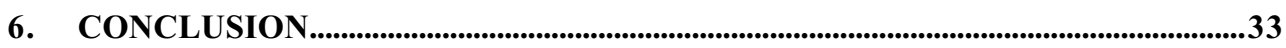

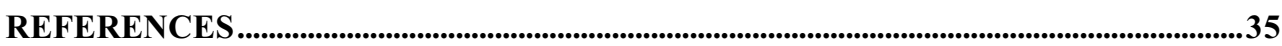

ANNEX 1: AVERAGE AND STANDARD-DEVIATION OF TARIFFS

IN THE BENCHMARK AND AS A RESULT OF EACH SCENARIO,

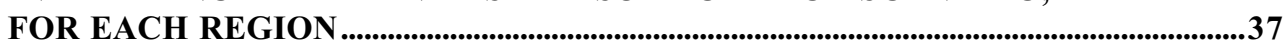

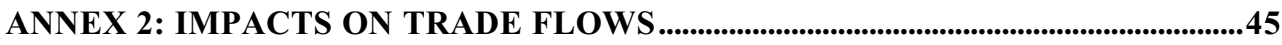

LIST OF WORKING PAPERS RELEASED BY CEPII...................................................47 



\section{MARKET ACCESS LIBERALISATION IN THE DOHA ROUND: SCENARIOS AND ASSESSMENT}

\section{SUMMARY}

The Doha ministerial declaration concerning market access for non-agricultural products states that negotiations should aim, by modalities to be agreed, to reduce or as appropriate eliminate tariffs, including the reduction or elimination of tariff peaks. On the agricultural side of the negotiation, market access is also a key item. The United States propose to adopt a Swiss formula, ensuring no individual tariff exceeds $25 \%$ after the phase-in period; the EU proposes in contrast a $36 \%$ reduction on average with a minimum reduction of $15 \%$ per tariff line; lastly, the revised Harbinson proposal suggests using a simple average for all agricultural products, subject to a minimum reduction per tariff line, with reduction coefficients increasing in the tariff level.

Accordingly, one of the key item of the agenda is to define a general formula reducing tariffs on a systematic basis, in particular tariff peaks, without excluding a special and differential treatment (SDT) for developing countries, namely less than reciprocal commitments. Such approach raises various issues. First, ad valorem equivalent of specific duties, have to be calculated. Second, tariff reduction should be modelled at the detailed level in order to avoid aggregation bias. Third, formula allowing developing countries to limit their commitments have to be envisaged.

Three categories of tariffs will be distinguished during the negotiation. Nuisance tariffs are very low and constitute more a transaction cost than an effective means of protection and can be eliminated accordingly. Moderate tariffs protect activities when the price elasticity of demand is high: here a simple linear formula of reduction can be applied. Lastly tariff peaks are a more sensitive issue and could eventually be reduced by a non-linear formula.

Against this background, this paper aims at addressing the impact of non-linear (Swiss) versus linear formulas, at measuring the impact of including or excluding peaks, the impact of the SDT eventually conceded to developing countries, and lastly at considering the consequences of the possibility for developing countries to reduce their tariffs (in relative terms) less than industrial countries.

Detailed information on tariffs and tariff equivalents, derived from MAcMaps, for some 5,000 categories of products is mobilised. It confirms that tariffs still matter, leaving scope for negotiation, in particular concerning the numerous tariff peaks in labour intensive manufactures and in agriculture.

Scenarios are defined at this detailed level of aggregation for 137 importing countries, taking into account the calendar of the phasing in of the agreement. The scenarios are based on a systematic rule of evolution of tariffs, conditional to their initial level. The agreement is supposed to be phased in within six years by developed countries and within ten years by 
developing countries. Each of the four considered scenarios includes a removal of nuisance tariffs (below $2 \%$ ).

The impact of these scenarios are finally assessed using MIRAGE, a dynamic CGE model incorporating imperfect competition and adjustment costs. Original aggregation procedures towards the GTAP5 sectoral classification allow introducing in the model results of the detailed analysis on tariffs.

The benchmark scenario (a) of a uniform 35\% lowering in tariffs raises welfare in each area between $0.2 \%$ and $0.9 \%$. Such limited amount is in line with other estimates, since we restrict our analysis on market access for products. The largest gains are obtained in Japan and in developing Asia, where the liberalisation impact is concentrated in agriculture, translating in sizeable consumers' gains, whereas land suffer a real loss in both areas, especially in Japan. The same kind of outcome is obtained for the EU and the rest of the world, but much smoother. The mirror image is given by the impact on the US and the Cairns group, due to their status of exporters of agricultural goods. The associated gains in welfare for both areas remain however limited. The situation of ACP countries appears as intermediate, due to the terms-of-trade loss.

Exempting tariff peaks from liberalisation in scenario (b) leads to welfare gains and trade creation in volume that are halved. The most important change, compared to scenario (a), is probably for Japan, where agriculture's liberalisation is very limited when tariff peaks are excluded.

Scenario (c ) implements a truncated Swiss formula: up to the tariff peak, the linear formula of scenario (a) applies, while the coefficient of reduction increases in the initial tariff thereafter. Compared to scenario (a), trade creation is higher, by $10 \%$ to $30 \%$. In terms of welfare, Japan gains to its own liberalisation (1.5\% of welfare as compared to $0.9 \%$ ), additional gains being more limited for Cairns (one decimal point) and Developing Asia (3 decimal points). For the remaining regions, the gains are hardly changed.

The concession of the SDT in scenario (d), gives raise to a slight redistribution of the gains from developed to developing countries. The main channel through which the redistribution is obtained is the real exchange rate, and therefore the terms of trade.

\begin{abstract}
The modalities of negotiation on market access for agricultural and non-agricultural products are an important item of the Doha Development Agenda. The dispersion of tariffs remains very large, translating in sizeable economic distortions. In particular, tariff peaks are numerous and highly protective. This is why the choice of a formula of reduction in tariffs is a sensitive issue. Using MAcMaps, we apply various formulas excluding or including peaks to detailed and exhaustive information on tariffs, considering preferential schemes conceded so far. The resulting changes in tariffs are introduced in a CGE exercise
\end{abstract}


using MIRAGE. We find that trade and welfare gains are halved when excluding peaks from the negotiations. However, considering redistribution of real incomes, the political economy of trade protection makes it hardly plausible to reach an agreement on an ambitious formula in agriculture.

JEL Classification: $\mathrm{D} 58 ; \mathrm{F} 12 ; \mathrm{F} 13$

Key Words: Market access; Doha Development Agenda; Tariff peaks; Computable General Equilibrium model. 



\section{LIBERALISATION DE L’ACCES AU MARCHE DANS LE CYCLE DE DOHA : SCENARIOS ET EVALUATION}

\section{RESUME}

Les négociations relatives à l'accès au marché pour les produits non agricoles doivent porter, aux termes de la déclaration ministérielle de Doha, sur des modalités à définir permettant de réduire voire d'éliminer les droits de douane, y compris les pics tarifaires. Concernant les produits agricoles, l'accès au marché apparaît aussi comme un enjeu majeur. Les Etats-Unis proposent d'adopter une formule suisse pour ramener les droits de douane à un maximum de $25 \%$ au terme du calendrier de désarmement douanier; l'Union européenne propose au contraire une réduction moyenne de $36 \%$ des droits, avec une exigence de réduction minimale de $15 \%$ par ligne tarifaire ; enfin la proposition Harbinson (révisée), suggère d'utiliser une moyenne simple pour tous les produits agricoles, avec une réduction moyenne par ligne et des coefficients de réduction augmentant avec le tarif initial.

Ainsi, l'un des aspects essentiels de l'agenda sera de définir une formule à caractère général permettant de réduire les droits de façon systématique, en particulier les pics, sans remettre en cause le principe du traitement spécial et différentié (TSD) permettant aux pays en développement de prendre des engagements asymétriques de réduction. Une telle démarche soulève plusieurs questions. Tout d'abord, des équivalents ad valorem des droits spécifiques devront être calculés. Ensuite, la modélisation du démantèlement tarifaire devra être faite à un niveau de détail élevé pour éviter un biais d'agrégation. Enfin, il convient d'envisager une formule permettant aux pays en développement de limiter leurs engagements.

Trois catégories de droits seront distinguées pendant la négociation. Les droits de nuisance, de faible niveau et qui constituent un coût de transaction plutôt qu'un moyen efficace de protection ; leur suppression peut donc être envisagée. Les droits modérés protègent les activités si l'élasticité prix de la demande est suffisamment élevée : on peut leur appliquer une formule de réduction linéaire. Enfin les pics constituent un sujet plus sensible et pourraient éventuellement être réduits par une formule non linéaire.

Cet article vise à comprendre l'impact de l'application d'un formule non linéaire (suisse), plutôt que d'une formule linéaire, à mesurer l'impact de la prise en compte ou de l'exclusion des pics de l'accord de désarmement douanier, enfin à mesurer l'impact du TSD concédé aux pays en développement.

Nous mobilisons une information détaillée sur les droits de douane et les équivalents tarifaires tirée de MAcMaps, pour quelque 5000 produits et 137 pays importateurs. La résistance des protections douanières est confirmée, en particulier dans l'agriculture et pour les industries de main-d'œuvre. Il y a donc matière à négociation. 
Des scénarios de libéralisation sont définis à ce niveau de détail, en prenant en compte le calendrier de mise en œuvre de l'accord (6 ans pour les pays industrialisés et 10 ans pour les pays en développement), sur la base d'une règle systématique d'évolution des droits de douane, conditionnelle à leur niveau de départ. Chacun des quatre scénarios envisagés comporte une suppression des droits de nuisance (inférieurs à $2 \%$ ).

L'impact de ces différents scénarios est finalement estimé à l'aide de MIRAGE, un MEGC dynamique en concurrence imparfaite comportant des coûts d'ajustement. Des procédures d'agrégation originales permettant de revenir vers la nomenclature sectorielle GTAP5 permettent d'introduire les résultats détaillés de l'étape précédente dans le modèle.

Le scénario (a) de référence, supposant un baisse uniforme de 35\% des droits, accroît le bien-être des différentes régions du monde de $0,2 \%$ à $0,9 \%$. Un accroissement aussi modeste est également trouvé dans les travaux comparables, dès lors que l'on restreint l'exercice à l'accès au marché des biens. Les gains les plus importants sont obtenus par le Japon et l'Asie en développement, où l'impact de la libéralisation se concentre dans l'agriculture, induisant des gains importants pour les consommateurs, tandis que les revenus réels de la terre diminuent dans ces deux régions. Le même type d'évolution, mais beaucoup plus amortie, est obtenu en Europe et dans la région Reste du monde. L'image inversée est renvoyée par les Etats-Unis et le groupe de Cairns, en raison de leur statut d'exportateurs de produits agricoles, sans que les gains de bien être associés y soient très importants. La situation des pays ACP est intermédiaire, en raison d'une perte de termes de l'échange.

L'exemption des pics du processus de démantèlement tarifaire dans le scénario (b) réduit environ de moitié les gains de bien être et la création de commerce. Par rapport au scénario (a), les différences les plus importantes sont observées pour le Japon, qui libéralise très peu l'accès à ses marchés agricoles dès lors que les pics sont exclus.

Le scénario (c) s'appuie sur une formule suisse tronquée, correspondant au scénario (a) jusqu'au niveau des pics tarifaires, l'application de la formule non linéaire prenant effet seulement ensuite. Par rapport au scénario (a), on obtient une augmentation plus importante des échanges, de l'ordre de $10 \%$ à $30 \%$. En termes de bien-être, le Japon bénéficie fortement de sa propre libéralisation $(1,5 \%$ de bien-être contre $0,9 \%)$, les gains supplémentaires étant plus limités pour le groupe de Cairns (un dixième de point de pourcentage) et l'Asie en développement (respectivement trois dixièmes). Pour les autres régions, les résultats des deux scénarios sont comparables.

La concession d'un TSD aux pays en développement dans le scénario (d) conduit à une légère redistribution des gains en direction de ces pays. Le principal canal de transmission est ici celui du taux de change réel, et donc des termes de l'échange. 


\section{RESUME COURT}

Les modalités de négociation relatives à l'accès au marché pour les produits agricoles et non agricoles constituent un élément important de l'agenda pour le développement du cycle de Doha. La dispersion des droits de douane demeure élevée, et induit des distorsions économiques importantes. En particulier, il existe de nombreux pics tarifaires très protecteurs. C'est pourquoi le choix d'une formule de réduction des droits de douane constitue un sujet difficile de négociation. Nous appliquons diverses formules incluant ou excluant les pics tarifaires à une information exhaustive et détaillée sur les droits de douane, en prenant en compte les préférences commerciales accordées jusqu'ici, en nous appuyant sur MAcMaps. Les variations correspondantes de protection sont introduites dans un exercice de simulation avec le MEGC MIRAGE. Nous montrons que les gains de commerce et de bien être sont réduits de moitié si les pics sont exclus de la négociation. Néanmoins, à l'aune de l'ampleur des redistributions de revenus réels, l'économie politique de la protection amène à douter de l'acceptabilité d'un accord sur une formule ambitieuse de libéralisation tarifaire dans l'agriculture.

Classification JEL : D58; F12; F13

Mots-clefs : Accès au marché; Agenda de Doha pour le développement; pics tarifaires; modèle d'équilibre général calculable. 



\title{
MARKET ACCESS LIBERALISATION IN THE DOHA ROUND: SCENARIOS AND ASSESSMENT
}

\author{
Lionel Fontagné, Jean-Louis Guérin \& Sébastien Jean ${ }^{1}$
}

\section{INTRODUCTION}

The Doha Development Agenda (DDA) aims at better integrating developing countries, especially Least Developed Countries (LDCs), in the multilateral trading system. The Ministerial declaration stresses that "international trade can play a major role in the promotion of economic development and the alleviation of poverty. We recognise the need for all our peoples to benefit from the increased opportunities and welfare gains that the multilateral trading system generates." Considering this ambitious target - WTO is not a development agency after all - issues of interest to developing countries should be priority items.

Accordingly, implementation issues are firstly raised in the associated Agenda. They derive from the discontent of developing countries, which consider having agreed on too tight commitments (concerning the intellectual property in particular), whereas industrialised countries have not respected their own commitments concerning market access for textile and clothing. Then comes agriculture: export subsidies, distorting domestic support and market access are at stake. Agriculture remains highly protected after the Uruguay round, notably a result of dirty tariffication, and numerous developing countries see this as a major obstacle to the development of their exports. On services, the request and offer procedure make it difficult to identify the possible outcome of the negotiations, but the mode IV is of course of particular interest to developing countries. Market access for non-agricultural products is the next item: market access in labour intensive industries in only part of the story. The Ministerial declaration states that negotiations should aim "by modalities to be agreed, to reduce or as appropriate eliminate tariffs, including the reduction or elimination of tariff peaks, high tariffs, and tariff escalation, as well as non-tariff barriers, in particular on products of export interest to developing countries. Product coverage shall be comprehensive and without a priori exclusions. The negotiations shall take fully into account the special needs and interests of developing and least-developed country participants, including through less than full reciprocity in reduction commitments, (...)". Then come Singapore issues.

This glance at the DDA stresses the importance of the modalities to be agreed, the objective of eliminating tariff peaks, and the commitment to avoid any exclusion. To put it in simple words, one of the key item of the agenda is to define a general formula cutting tariffs on a systematic basis, without excluding a special and differential treatment (SDT) for developing countries, namely less than reciprocal commitments. Such formula approach is

The authors would like to thank Mondher Mimouni (ITC) for his efficient help in designing the scenarios and more generally his work on MAcMaps, and Hedi B'chir (CEPII) for helping with the computations. 
rather pragmatic: given the number of interested parties in the negotiation, any means allowing to simplify the negotiation will be preferred (Francois and Martin, 2003). This is why the main proposals made so far have all attempted to propose original formulas.

The US proposal for non agricultural products - branded as "A Tariff-Free World" suggests using a tariff equaliser (a Swiss formula in practice) driving to a maximum tariff of $8 \%$ in 2010 , before implementing a second -linear- tariff reduction to zero over 20102015. The Japanese formula would allow members to reduce their trade-weighted tariff average to a target level, the coefficient of reduction being increasing with the initial averages. The China's proposal is a more complex Swiss formula taking into account the simple average of the base rates, and a definition of peaks in proportion of this average rate. The European formula defines two intervals of initial tariffs, and applies a formula of reduction within these intervals. In addition, tariff peaks (above 50\%) would be all compressed to $25 \%$. Lastly, the Girard proposal is based on a Swiss formula in which the coefficient of reduction is depending on the initial average rate.

On the agricultural side of the negotiation, market access is also a key item. The United States propose to adopt a Swiss formula on ad valorem as well as specific applied tariffs, ensuring no individual tariff exceeds $25 \%$ after the phase-in period; the EU proposes in contrast a $36 \%$ reduction on average with a minimum reduction of $15 \%$ per tariff line; lastly, the revised Harbinson proposal aims at reducing tariffs, except in-quota tariffs, by a simple average for all agricultural products, subject to a minimum reduction per tariff line. Three intervals are considered, in which reduction rates are increasing in the initial rates up to $60 \%$ for peak products (corresponding to duties above $90 \%$ ).

This formula approach raises various issues. First, since it is applied to ad valorem duties or ad valorem equivalent of specific duties ${ }^{2}$, the latter equivalents have to be calculated. Second, formulas will be implemented on a tariff line basis. Hence, it is important to model tariff reduction at the detailed level in order to avoid aggregation bias (Martin et al, 2003). Third, formula allowing developing countries to limit their commitments have to be envisaged. In total, how the choice of a formula impacts world trade, factor incomes and welfare of groups of countries interested in the negotiation remains unclear.

To better examine these proposals, three categories of tariffs have to be distinguished. A first category corresponds to tariffs that can be eliminated without too much care: these are very low tariffs that are much more a transaction cost than an effective means of protection. And as government revenue is concerned, common sense suggests that such duties are not worth the efforts spent to recover them. These "nuisance tariffs" could be dropped easily. The second category is moderate tariffs: they do protect activities, most of all when the price elasticity of demand is high. Progress could be made here by simply linearly cutting these tariffs by a certain percentage: the "average reduction in tariffs". Lastly, tariff peaks are a more sensitive issue: compressing these tariffs would be good news for world trade.

${ }^{2}$ With the exception of the American proposal which aims at directly reducing specific tariffs. 
However, there is no guarantee that an agreement will be found here, in particular if one adopts a formula that dramatically reduces the highest tariffs.

Against this background, this paper aims at addressing the impact of non-linear (Swiss) versus linear formulas, at measuring the impact of including or excluding peaks, the impact of the SDT eventually conceded to developing countries, and lastly at considering the consequences of the possibility for developing countries to reduce their tariffs (in relative terms) less than industrial countries.

In order to qualify better the results, we rely on information at the most detailed level of existing information, considering various elements such as ad valorem tariffs, specific duties, prohibitions, tariff quotas, and anti-dumping duties. Ad valorem equivalents of all these instruments are derived from MAcMaps, the large database of trade barriers developed by CEPII and ITC, considering some 5,000 categories of products.

We define scenarios at this detailed level of aggregation, addressing the issues referred to above. Our liberalisation hypotheses are translated in terms of protection variations, using tariff equivalents for each of these instruments, on a bilateral basis for 137 countries and 220 suppliers. In practice, we simply apply various formulas at the HS-6 digit level of the nomenclature, for each product, for each importing country and vis-à-vis each exporter. We then use aggregation procedures minimising the traditional aggregation bias in order to go back to the breakdown of our CGEM in terms of regions and sectors. We aggregate the data in the GTAP5 sectoral classification, gathering countries into a limited number of geographic areas. The aggregation procedure defined in MAcMaps minimises the traditional endogeneity bias by relying on imports of reference groups. We also take into account the possibility - present in various proposals - to systematically eradicate very low tariffs. We lastly take into account the calendar of the phasing out, notably the possibility for developing countries to phase in the agreement over a longer implementation period.

The impacts of these scenarios are then assessed using MIRAGE ${ }_{5}^{4}$, a dynamic AGE model incorporating imperfect competition, foreign direct investment 5 and immobility of installed capital. The sequential dynamic structure of the model enables the liberalisation's timing to be taken into account. With the exception of protection data, for which MAcMaps is used as a source, as described above, the model is calibrated using the GTAP 5 database.

We are interested in market access for agricultural as well as non-agricultural products. The same set of generic formulas will be applied to the two items of the Agenda, but we will define differently tariff peaks in agriculture.

\footnotetext{
3 Market Access Maps. See Bouët et al., 2001.

Modelling International Relationships in Applied General Equilibrium

5

Here, the FDI module is not implemented, due to lack of data
} 
None of these scenarios precisely reproduces a given proposal. We take the removal of nuisance tariffs from various scenarios but set up a reasonable threshold. We rely on a (truncated) Swiss formula whereas various proposals do not use such possibility to linearly cut tariffs up to the threshold defining the peaks. We have chosen a threshold for tariff peaks in agriculture that corresponds roughly to the consensus, even though it is not present as such in any proposal. We consider alternatively an average reduction of tariffs, notwithstanding the opportunistic attitudes of WTO members that will use such averaging process as a device to limit their own real commitments. We guaranty the concession of a SDT to developing countries based on the outcome of past negotiations (longer implementation period) and in conformity with the Doha Ministerial declaration (more limited commitments). We are accordingly interested in the comparison of scenarios (linear versus Swiss formula; average excluding or not the peaks; symmetric versus asymmetric commitments, etc.) and not in the assessment of a given scenario that would anyway hardly represent the outcome of the Round.

There are of course limitations associated with such an approach.

First, despite the high level of detail in MAcMaps, our exercise will consider cutting applied tariffs, whereas negotiations deal with bound tariffs (with the exception of the US proposal in agriculture). As some countries have bounded tariffs much above the applied rate, the final reduction in tariffs is more limited than simulated here (Walkenhorst and Dihel, 2002).

Second, since bilateral applied tariffs (and not MFN ones) are taken into account in MAcMaps, we apply the reductions in tariffs to these values, which integrate preferential treatment. As a result, the expected erosion of preferences associated with any severe cut in tariffs on a multilateral basis is slightly understated ${ }^{6}$.

Third, we do not consider domestic support and export subsidies in agriculture. Hence, there are additional gains to be considered but there is some evidence that market access is much more important for developing countries (FAPRI, 2002; Francois et al, 2003; Bouët et al, 2003; Hoekman et al, 2002-b). In the same way, gains to liberalisation in services should be added; but here, we are collectively missing reliable data. In total, the paper should be considered as a tentative assessment of the impact of using various formulas for market access are still a matter of negotiation, based on detailed data, rather than a complete evaluation of the Round. Accordingly, it addresses market access only, which is not the full Agenda.

The rest of the paper is organised as follows. Section 2 stresses the need for a disaggregated approach to the definition of scenarios, on the basis of recorded trade barriers. Tariff peaks, prohibitions, tariff quotas, anti-dumping as well as a high and intricate system of

\footnotetext{
Consider as an example, three MFN initial tariffs $(50 \%, 20 \%, 5 \%)$ and the corresponding preferential tariffs $(8 \%, 2 \%, 0 \%)$. A Swiss formula (coefficient: 25$)$ applied to the preferential and MFN tariffs (i.e. the bilateral tariffs), leads to more limited losses in preferential margins (-31.4/-8.7/-0.8 percentage points) as compared to a reduction in MFN tariffs only (-33.3/-8.9/-0.8 respectively).
} 
preferences are pointed out. Section 3 presents the model used to simulate the scenarios. Section 4 defines the scenarios. Section 5 draws the first conclusions. Section 6 concludes.

\section{AN OVERVIEW OF CURRENT PROTECTION}

Basically, given that one focuses on trade in merchandises, three sources of market distortions can be considered: border measures, domestic support and export subsidies. Domestic support and export subsidies are recorded in the GTAP database we will rely on, as well as modelled in our CGE, but we will not change their level in the current simulation exercise. On the contrary, bilateral tariff data at the detailed level requested by the definition of any sensible scenario must rely on more detailed sources of information.

MAcMaps ${ }^{7}$ is a bilateral measure of market access which has been constructed to integrate the major instruments of protection (ad valorem and specific duties, prohibitions, tariff quotas, anti-dumping duties) at the most detailed level (tariff lines), as well as all discriminatory regimes. Source information is derived from country sources (official journals, circulars and customs web sites), from TRAINS (UNCTAD) source files, AMAD, and notifications to the WTO regarding anti-dumping regimes. These files are combined with trade data from the COMTRADE (UNSD) database. The reference year for the current exercise is 1999 for tariff data and 1997 for GTAP5. As a consequence, initiatives recently taken in favour of LDCs, such as EBA and AGOA are not integrated in the baseline scenario, which will lead to an overestimation of gains accruing to beneficiaries as a result of improved market access for their exports.

The database groups the following instruments of protection: MFN duties, other ad valorem duties, specific duties, preferential margins, prohibitions, tariff quotas, anti-dumping (specific or ad valorem) duties. Ad valorem equivalents of each instrument are calculated at the tariff line level, using information on unit values at the 6-digit level of the HS. Thereafter the mean of ad valorem equivalents within each HS-6 category is simply calculated. Additional taxes that may be levied on imports are not reported. For each importing country, one records all the groups of countries that face the same regime, and for each trade regime the existence or absence of various barriers to trade (ad valorem duty, special tariffs, quotas, etc.). The source information must therefore be structured as a fourdimensional matrix (products * importing countries * exporting countries * instruments of protection). Data can be aggregated in the GTAP nomenclature using a procedure that minimises the endogeneity bias while accounting for the importance of products as well as countries in international trade (see Bouët et al, 2001).

\footnotetext{
7 A first release of MAcMaps aimed at exploring the possibilities of programming such a tool, while largely relying of source files of TRAINS. AMAD data and antidumping notifications were taken into consideration too. The corresponding results have been published in Bouët et al. (2001). The current exercise is based on a second release, that departs from the initial one by relying on national sources as often as necessary, by extensively covering anti-dumping practices, by endogenously defining the reference groups used in the aggregation procedures and lastly by fully covering the preferential agreements. A third release, considering the year 2001, is currently under check out by the GTAP consortium.
} 
A first glance at ad valorem duties stresses the relative similarity of average levels in the Triad. This five to six percent average is the outcome on which it is often claimed that tariffs do no longer matter. This is not the case however, since tariff peaks can be very large and disseminated throughout the tariff schedule, and since some sectors remain highly protected (agriculture, labour intensive industries). One tariff line out of 20 in the US, one out of 13 in the EU, and one out of 9 in Japan is a tariff peak (defined as a duty above $15 \%$, see Table 2.1).

In addition to this, numerous quantitative barriers have been transformed into specific duties as a result of the Uruguay Round, in agriculture. These duties have particularly spread throughout the US and European tariff schedules. These specific duties, when transformed in ad valorem equivalent using the unit value of the corresponding trade flows, can be very large. The average ad valorem equivalent is much larger than the one of ad valorem duties, in particular in Europe where it is ten times as large. Moreover, the frequency of tariff (equivalent) peaks is very large too: in Europe, two ad valorem equivalents of specific duties out of three can be referred to as peaks.

Altogether, the picture drawn up by MAcMaps confirms that tariffs still matter, leaving scope for negotiating: hence the diagnosis of "unfinished business" concerning market access (WTO, 2002).

Table 2.1: Ad valorem and specific duties in the Triad (1999)

\begin{tabular}{lccc}
\hline & USA & Japan & EU \\
\hline Ad valorem: & & & \\
Average duty (ad valorem duties) & $4.9 \%$ & $6.6 \%$ & $5.9 \%$ \\
Maximum duty (ad valorem duties) & $350 \%$ & $60 \%$ & $88.9 \%$ \\
Duties > 15\% (number) & 467 & 870 & 771 \\
Duty > 15\% (freq) & $5.4 \%$ & $11.5 \%$ & $7.5 \%$ \\
& & & \\
Specific duties: & & & \\
No. of specific duties & 1148 & 418 & 1059 \\
Average Ad valorem equivalent & $12.8 \%$ & $7.4 \%$ & $50.0 \%$ \\
Maximum Ad valorem equivalent & $310 \%$ & $171 \%$ & $326 \%$ \\
Number Ad valorem equivalent $>15 \%$ & 170 & 34 & 679 \\
Freq Ad valorem equivalent $>15 \%$ & $14.8 \%$ & $8.1 \%$ & $64.1 \%$ \\
\hline
\end{tabular}

Source: MAcMaps.

On top of this, a limited number of tariff quotas, generally enforced in agriculture, must be taken into consideration, as well as anti-dumping duties, dedicated to manufactures (see Table 2.2). In agriculture the inside quota rate can be very large, in particular in Japan, while antidumping duties are particularly enforced by the US. 
Table 2.2: Number of tariff quotas (1999), average IQTR and OQTR and anti-dumping duties in the Triad

\begin{tabular}{cccc}
\hline & USA & Japan & EU \\
\hline No. of tariff quotas & 21 & 20 & 54 \\
Average IQTR & $8.7 \%$ & $17.3 \%$ & $15.2 \%$ \\
Average OQTR & $41.8 \%$ & $234.8 \%$ & $60.2 \%$ \\
No. of anti-dumping duties & 673 & 42 & 367 \\
Source: MAcMaps & & &
\end{tabular}

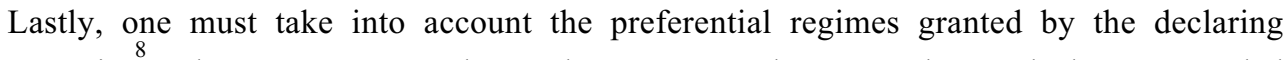
countries. The EU, Japan, and to a lesser extent the US and Canada have conceded preferential market access to certain exporting countries. As a result, a country having numerous tariff peaks or enforcing on average larger MFN tariffs can have a limited average tariff equivalent of all instruments, thanks to these preferences. This is where a bilateral approach to market access is worth; and this is where a tariff scheme highlighting a moderate tariff mean can still be highly distorsive.

One needs to aggregate our sample of 137 countries in order to go back to the regional break down of the CGE exercise. Convincingly, one can argue that agriculture will be a major topic to be discussed in the next round: hence, the European Union, the United States, Japan, the Cairns group that will be major players in the negotiation must be identified. Given the agenda of enlargement of Europe, an enlarged, 25 country EU (hereafter referred to as EU25) will be directly considered. ACP countries (or, more specifically African countries benefiting from the Cotonou agreement) raise specific issues that need to be addressed too: they have traditionally benefited from a very large margin of preference on the European market, and could be harmed by the erosion of their preferences (Fontagné and Mimouni, 2002). Besides, major players such as Europe, the US and Japan will seek increased market access on promising emerging markets: markets such as Brazil, India, China are of major interest. There is however a conflict of priorities in the aggregation procedure here, since some of the latter countries are already integrated in the Cairns group. The remaining emerging economies will be grouped in the developing Asia (AED) group. In total, the 66 GTAP regions will be grouped into the following 7 regions: USA, Japan, EU25, Cairns, ACP, AED, RoW.

An overview of estimated protection at the aggregated sector- and region-level of this classification highlights that there is much room for negotiation (Graph 2.1). Numerous tariff peaks are recorded, even at the level of the sector, while many tariffs are low enough for being nuisance rather than offering a true protection. Even at this level, there are more than $25 \%$ of sectors in which the bilateral protection is lower than $2 \%$, all instruments being considered.

\footnotetext{
${ }^{8}$ There is a loophole in the methodology: quotas in agriculture are not recorded on a bilateral basis. The quota and the procedure of allocation are known. The quantity imported, hence the quantity imported outside the quota is known. But how the quota has been allocated by the importing country among exporters is not known. Hence the calculation of a tariff equivalent of the tariff quota and the assumption that each exporter is facing this equivalent.
} 


\section{Graph 2.1: Tariff equivalents of all instruments at base year (by region and sector)}

tarifin

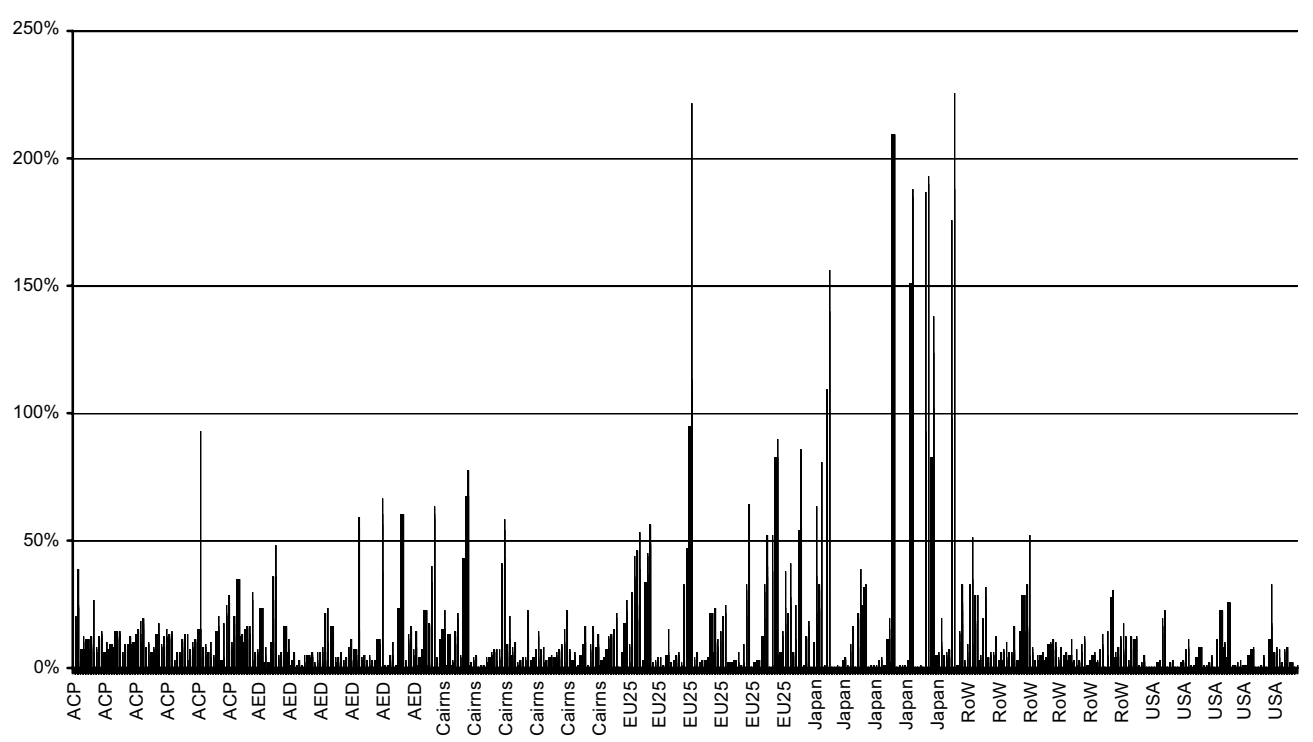

Source: MacMaps

Note:Each bar correspond to an ad valorem equivalent tariff, levied by one importer in one sector for one partner in the aggregation used for the simulation. The triplets are ordered alphabetically, according to importer, then to sector and finally to exporter.

First, the highest tariff equivalents of all instruments are enforced in agriculture, especially by Japan: Wheat, Meat, Oil seeds, Processed rice, Paddy rice, Dairy products, Sugar are sectors facing ad valorem equivalents larger than $100 \%$, and up to $225 \%$. Among these 21 observed cases (see Table 2.3), Japan accounts for 18 cases, and Europe 3. 
Table 2.3: Highest tariff equivalents of all instruments, by importing region, exporting region and sector (1999)

\begin{tabular}{lccc}
\hline Sector & importer & exporter & tariff \\
\hline Wheat & Japan & RoW & $225 \%$ \\
Meat: cattle, sheep, goat & EU25 & USA & $221 \%$ \\
Oil seeds & Japan & AED & $208 \%$ \\
Processed rice & Japan & Cairns & $193 \%$ \\
Processed rice & Japan & RoW & $190 \%$ \\
Wheat & Japan & ACP & $188 \%$ \\
Paddy rice & Japan & ACP & $187 \%$ \\
Processed rice & Japan & ACP & $187 \%$ \\
Paddy rice & Japan & Cairns & $184 \%$ \\
Wheat & Japan & AED & $175 \%$ \\
Dairy products & Japan & RoW & $156 \%$ \\
Paddy rice & Japan & RoW & $151 \%$ \\
Paddy rice & Japan & AED & $140 \%$ \\
Dairy products & Japan & AED & $140 \%$ \\
Sugar & Japan & Cairns & $137 \%$ \\
Sugar & Japan & RoW & $123 \%$ \\
Paddy rice & Japan & EU25 & $121 \%$ \\
Meat: cattle, sheep, goat & EU25 & AED & $113 \%$ \\
Meat: cattle, sheep, goat & EU25 & RoW & $109 \%$ \\
Dairy products & Japan & ACP & $109 \%$ \\
Sugar & Japan & ACP & $101 \%$ \\
\hline & & & \\
\hline
\end{tabular}

Source: MAcMaps

Within the 50-100\% range (Table 2.4), one finds the same sectors, EU25 appearing more often, as well as Developing Asia (AED). Surprisingly, but this might be the outcome of the aggregation of very different situations among countries, the Cairns group does impose, on average, high protection for certain items such as dairy or meat products. 
Table 2.4: Tariff equivalents $[50 \%, 99 \%]$ by importing and exporting region and sector (1999)

\begin{tabular}{lcccllcc}
\hline Wheat & Japan & USA & $98 \%$ & Cattle, sheep, goase & Japan & AED & $63 \%$ \\
$\begin{array}{l}\text { Meat: cattle, } \\
\text { sheep, goat }\end{array}$ & EU25 & ACP & $95 \%$ & Wheat & AED & RoW & $63 \%$ \\
Paddy rice & ACP & Japan & $93 \%$ & Sugar & Japan & EU25 & $63 \%$ \\
Processed rice & Japan & AED & $93 \%$ & Wheat & AED & Cairns & $61 \%$ \\
Processed rice & Japan & EU25 & $90 \%$ & Sugar & Japan & USA & $60 \%$ \\
Sugar & EU25 & AED & $90 \%$ & Paddy rice & AED & Cairns & $60 \%$ \\
Meat: cattle, & EU25 & Japan & $90 \%$ & Processed rice & AED & RoW & $60 \%$ \\
sheep, goat & & & & & & & \\
Wheat & Japan & EU25 & $87 \%$ & Sugar & EU25 & Cairns & $59 \%$ \\
Wheat & Japan & Cairns & $85 \%$ & Oil seeds & AED & USA & $59 \%$ \\
Sugar & Japan & AED & $83 \%$ & Meat products nec & Cairns & AED & $59 \%$ \\
Sugar & EU25 & RoW & $82 \%$ & Wheat & AED & USA & $58 \%$ \\
Cereal grains nec & Japan & RoW & $81 \%$ & Dairy products & EU25 & Cairns & $56 \%$ \\
Dairy products & Japan & Cairns & $79 \%$ & Paddy rice & AED & USA & $56 \%$ \\
Dairy products & Cairns & EU25 & $77 \%$ & Oil seeds & AED & Cairns & $55 \%$ \\
Dairy products & Japan & EU25 & $75 \%$ & Meat products nec & Cairns & Cairns & $54 \%$ \\
Dairy products & Cairns & Japan & $67 \%$ & Wheat & EU25 & AED & $54 \%$ \\
Paddy rice & AED & RoW & $66 \%$ & Sugar & EU25 & ACP & $53 \%$ \\
Sugar & EU25 & USA & $65 \%$ & Processed rice & EU25 & USA & $52 \%$ \\
Meat: cattle, & EU25 & Cairns & $65 \%$ & Meat: cattle, sheep, & RoW & RoW & $52 \%$ \\
sheep, goat & & & & goat & & & \\
Dairy products & Cairns & Cairns & $64 \%$ & Cattle, sheep, goase & RoW & AED & $51 \%$ \\
Paddy rice & EU25 & USA & $64 \%$ & & & \\
\hline Source: MAcMaps & & & & & &
\end{tabular}

\section{The MODEL Mirage}

This Section proposes a very brief overview of the model MIRAGE. ${ }^{9}$ The main characteristics of the model concern the assumptions made about products quality ranges, imperfect competition, capital, and dynamic aspects. Given the difficulty to gather satisfactory data for the rather detailed classification used here, FDI is not taken into account.

\subsection{Demand}

The demand side is modelled in each region through a representative agent, whose utility function is intra-temporal, with a fixed share of the regional income allocated to savings, the rest used to purchase final consumption. Below this first-tier Cobb-Douglas function,

9 A detailed presentation of the technical aspects of Mirage is available in Bchir et al. (2002). 
the preferences across sectors are represented by a LES-CES function. Each sectoral subutility function is a nesting of CES functions, comparable to the standard nested Armington - Dixit-Stiglitz function, with two exceptions:

- Products originating in developing countries and in developed countries are assumed to belong to different quality range. Their substitutability is therefore assumed to be weaker than the substitutability between products from the same quality range, which is for products from developed (developing) countries between each other.

- Domestic products benefit from a specific status for consumers, making them less substitutable to foreign products than foreign products between each other, within a given quality range.

\subsection{Supply}

Production makes use of five factors: Capital, Labour (skilled and unskilled), Land and Natural Resources. The first three are generic factors, whereas the last twos are specific ones. The production function assumes perfect complementarity between value added and the intermediate consumption. The sectoral composition of the intermediate consumption aggregate stems from a CES function. For each sector of origin, the nesting is exactly the same as for final consumption, meaning that the sector bundle has the same structure for final and intermediate consumption.

The structure of value added is intended to take into account the well-documented skillcapital relative complementarity. These two factors are thus bundled separately, with a lower elasticity of substitution (0.6), while a higher substitutability (elasticity 1.1) is assumed between this bundle and all other factors.

\subsection{Competition}

Aside competitive, constant returns to scale sectors, rather well suited to describe agricultural sectors, the model also includes oligopolistic sectors. Perfectly competitive sectors face constant returns to scale (CRTS) in production. In oligopolistic industries, firms face a constant marginal cost and a fixed cost, expressed in output units. Firms compete à la Cournot, with zero conjectural variations, no Ford effect, and no strategic interaction.

As far as the dynamics of market structure is concerned, two kinds of oligopolistic sectors are considered, fragmented and segmented ones. The difference between these two sector classes lies in the number of firms evolving more slowly in segmented sectors than in fragmented ones. The zero-profit assumption is thus the long-term target, but the sticky entry-exit of firms makes the adjustment progressive, with longer delays in segmented sectors.

${ }^{10}$ Practically this is done by assuming, for each new period, that profits are lowered by $20 \%$ in segmented sectors and by $50 \%$ in fragmented ones, compared to the level they would have reached, had the number of firms remained inchanged. 


\subsection{Capital and investment}

Capital, whatever its origin, domestic or foreign, in a given region, is assumed to be obtained by assembling intermediate inputs with the same nesting as in intermediate consumption. Only the share coefficients differ, and no factor service is needed. The capital good is the same whatever the use sector.

Installed capital is considered to be totally immobile. This putty-clay hypothesis is very important, because it implies that the adjustment in the capital stock is gradual. As a consequence, capital stock allocation may be under-optimal, and the rate of return to capital may differ between sectors. In addition, the capital market clearing only concerns new capital.

This gives investment an important role, as the only adjustment device for capital stock. The investment description in MIRAGE intends to propose a generic model for investment, which is coherent with a rational behaviour of investors. The basic principle is that the allocation of investment across sectors stems from sectoral capital rates of return. The parameters are such that, for a variety of small commercial shocks, half the adjustment of capital stocks towards the long run target would be made in around 4 years.

\subsection{Closure and markets clearing}

Product markets clearing is obtained by equating, for each variety, output to the three kinds of uses, namely intermediate consumption, final consumption, and part of capital good. Production factors are assumed to be fully employed. However, imperfect mobility of some production factors is assumed so as to take better into account the problems caused by massive reallocation effects. As outlined above, installed capital is immobile, and market clearing only concerns savings and investment. Natural resources are also perfectly immobile and may not be accumulated. The prices of those last two factors may thus differ among sectors of use. The two forms of Labour, as well as Land, are perfectly mobile among sectors. ${ }^{12}$ Except capital, all factors are immobile internationally.

The macroeconomic closure is obtained by assuming that for capital movements other than FDIs (that could be called the purely financial component of capital movements, as opposed to the industrial motivation of FDIs), the net balance is exogenous (and equal to its initial value). As a result, the current balance of each area only depends on net FDI flows. And of course, the revenue of capital accrues to the source country's income.

\footnotetext{
11 The program checks that the Walras' law is always respected. 12

The stickiness of some factor markets may strongly modify the impacts of liberalisation episodes. For tractability sake, we however decided to leave aside considerations of short-run unemployment and wages rigidities.
} 


\subsection{Dynamic issues}

Dynamic gains from trade can be assessed using MIRAGE, since the immobility of installed capital and the inertia in the adjustment of the number of firms allow a realistic description of the adjustment process to be proposed. As the dynamic setting is recursive, the time scope can be freely chosen (here, 12 years), and a shock can be introduced at each period. The reallocation of either totally or partially mobile factors is complete between each considered period. Factor endowment evolutions and training (the transformation of unskilled labour into skilled labour) between periods are given. Total factor productivity is assumed to remain unchanged (no externality is assumed to hold, although gains à la Ethier, linked to an easier access to intermediate inputs can arise). The continuous liberalisation does impact the various sectoral rental rates of capital: this in turn does lead to an impact on investment (and FDI) allocation. At the same time, the profit rate and the number of firms in imperfectly competitive sectors do also evolve toward the long run conditions under free entry of firms.

\section{SCENARIOS}

In order to provide a basis for the simulation exercise, the alternative agendas of tariff cuts mentioned above need to be translated into scenarios, that is in quantified changes of trade barriers in each sector, for each bilateral trade flow between regions, for each year of the phase-in period. This exercise is carried out here based on the MAcMaps database. While it allows the most detailed information to be taken into account, it is subject to various constraints.

Five types of protection instruments a taken into account: ad-valorem tariffs, specific duties, tariff quotas, prohibitions, anti-dumping duties. The information considered here refers to the ad valorem equivalent tariff of these instruments considered globally. This implies defining scenarios on this global ad valorem equivalent. Services are not covered by MAcMaps, and GTAP provides limited information, which restricts this study to market access for products.

The same generic formula is applied to agricultural and non-agricultural products. However, the threshold for defining tariff peaks differ, in order to take into account the specificity of the negotiation on market access for the former category of products ${ }^{14}$. In the same way, the SDT conceded to developing countries is based on a smoother coefficient of reduction in tariffs (in the last scenario), and a longer phase-in period (in all scenarios). These are rather simple means of considering in a single scheme the various strands of negotiations. We define tariff peaks as those above $15 \%$ for non-agricultural products

\footnotetext{
13

This may change the time spend in solving the model, but it has no impact on the feasibility. 14

In addition to reduction in tariffs, the negotiation could also end up by requiring the enlargement of tariff quotas, the abolition of inside tariff quotas, etc. All these issues are too specific and too uncertain to justify the associated modelling effort. Hence, even if a detailed treatment of information could authorise to tackle such issues, they have not been considered here.
} 
(which is the standard international definition), and those above $85 \%$ in agriculture and agro-food.

The scenarios share the following characteristics:

- They are based on a systematic rule of evolution of the ad valorem tariff equivalent of the five protection instruments (ad-valorem tariffs, specific duties, tariff quotas, prohibitions, anti-dumping duties) considered a whole;

- This rule of evolution is conditional to the initial level of the ad valorem tariff equivalent;

- The agreement is to be phased in progressively within six years by developed countries and within ten years by developing countries, through identical yearly steps in both cases. However, since this different timing is applied to regions as a whole, we do once again face a conflict of priorities concerning the Cairns group. This group was eventually subject to the SDT conceded to developing economies, given its composition. We decided not to adopt such simplification, but to implement the SDT on a country-by-country basis, before aggregating countries within regions. Accordingly, only developing countries of the Cairns group are conceded a SDT, even though if the region mixes developed and developing economies. Asia, ACP countries and the rest of the world are also considered as developing regions.

- Each scenario includes a removal of nuisance tariffs, defined as HS-6 products with an ad valorem tariff equivalent below $2 \%$.

In order to clearly assess the role of the choice of a formula, four scenarios are considered:

(a) Uniform: Lowering of the ad valorem tariff equivalent by 35\% for each HS6 product. This is the benchmark-scenario, if not necessarily a realistic assumption: even the choice of relying on averages defended in certain proposals would lead to much differentiated tariff cuts at the product level (hence the difference between average reduction and reduction of the average).

(b) Uniform, except peaks: Lowering of the ad valorem equivalent tariff by $35 \%$ for each HS6 category of products, except for those protected initially by a peak (i.e., HS-6 products with an initial ad valorem equivalent above $15 \%$ in manufacturing, and to $85 \%$ in agriculture). The comparison with the benchmark scenario will provide a crude welfare estimate of the cost of exempting peaks from the tariff cut.

\footnotetext{
15

The removal of nuisance tariffs is not recalled in each definition, but it is included in each scenario. Accordingly, the "uniform" scenario is thus not exactly uniform.
} 
(c) Harmonizing ("truncated Swiss formula"): Non-peak ad valorem equivalent tariffs are lowered by $35 \%$, while tariff peaks are cut through a Swiss formula (by which the initial tariff $t_{\text {ini }}$ lowered to $t_{\text {final }}$, defined by $t_{\text {final }}=\frac{a t_{\text {ini }}}{a+t_{i n i}}$ ). The coefficient $a$ of this formula is defined such as to ensure the continuity of the lowering percentage of the tariff as a function of its initial level ( $a=28$ in manufacturing, 158 in agriculture). ${ }^{16}$ Following the conventional wisdom that the cost of a tariff is a quadratic function of its level, this scenario combining a minimum $35 \%$ lowering of tariffs with a severe cut in tariff peaks is likely to be significantly more beneficial to welfare, in average, than the previous two. However, one should stress that the formula applied is rather moderate as far as agricultural products are concerned: below tariff equivalents of $85 \%$, there is no difference here for these products between scenarios (a), (b) and (c).

(d) Harmonizing+SDT: This scenario combines a severe reduction of tariff peaks with the necessity to concede developing countries a SDT. It is identical to the previous one for developed countries. For developing countries, a "truncated Swiss formula" is also applied, but with a lowering of $20 \%$ for non-peak tariffs, and with a coefficient of the Swiss formula applied to peaks calculated, as before, so as to ensure the continuity of the lowering rate of tariffs ( $a=60$ in manufacturing, 340 in agriculture). This hypothesis, and the corresponding coefficients, is applied for each country separately, before aggregating into regions (see Annex for the distribution of countries into developed and developing ones). .

The outcome of these scenarios is plotted in Figure 1 for non-agricultural products.

The impact of these scenarios on the observed applied levels of protection in 1999 is illustrated through Table A1 to A7 in Annex. For each region, the corresponding Table shows, for the benchmark and after the complete phasing-in of each scenario, the average AVE tariff applied. MAcMaps tariffs are used at the bilateral level in the model but here, for the sake of illustration, a trade-weighted average is calculated across partners. To illustrate the discrimination underlying this average level, the standard deviation of AVE tariffs across partners is also shown. This standard deviation is calculated without any weighting, in order to avoid any endogeneity bias, likely to be especially high as far as discrimination is concerned.

\footnotetext{
16

In manufacturing, for instance, coefficient $a$ is calculated such that an initial tariff of $15 \%$ is lowered by $35 \%$. It is therefore equal to $15 *(100-35) / 35=28$.
} 
Figure 1: Hypothetical tariff reductions in the four scenarios (for manufacturing)

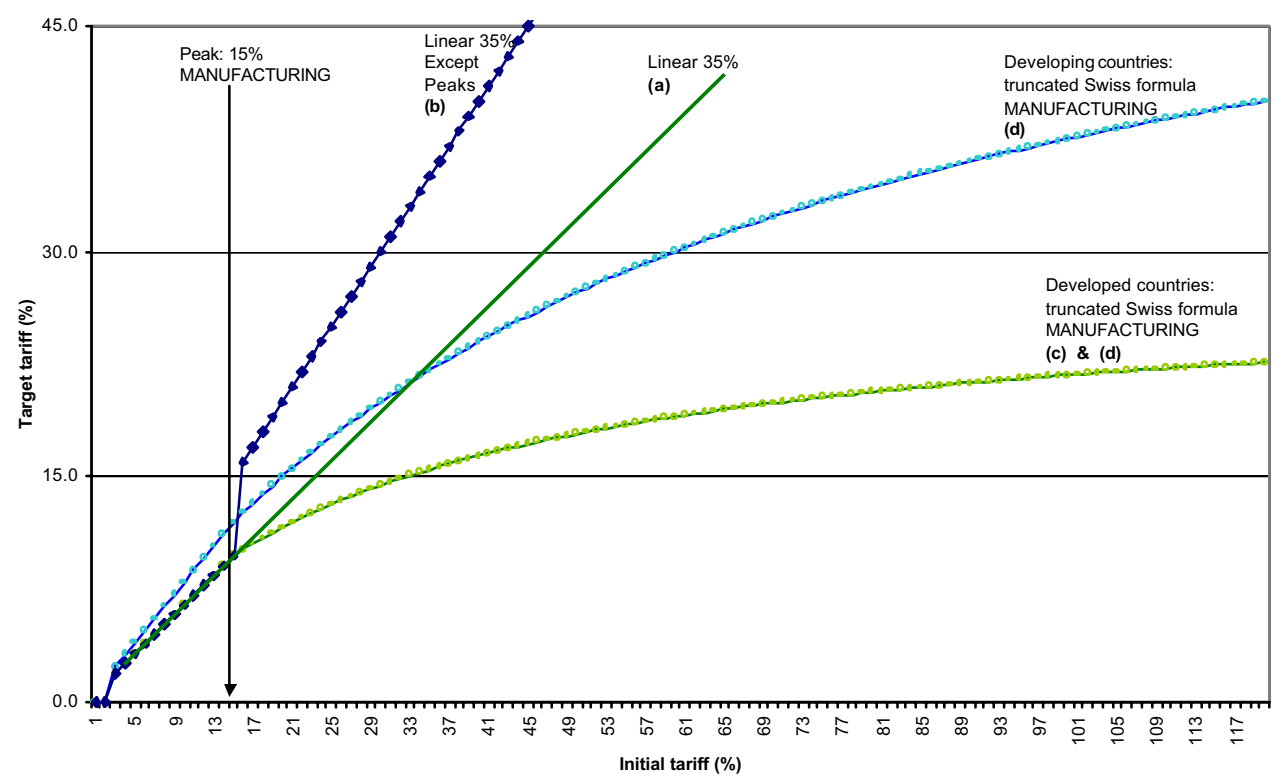

\section{RESULTS}

As outlined above, the rather simple assumptions used to build liberalisation scenarios actually lead to a complex set of changes in the applied level of protection, given its initial structure. Simulating the consequences of each scenario allows a broad assessment of the impact of choosing a formula to be proposed. The main results are summarised in Table 5.1 through 5.4. Trade details can also be found in the tables of Annex 2.

The benchmark scenario (a) of a uniform $-35 \%$ tariff cut raises welfare of the representative agent in each area, between $0.2 \%$ and $0.9 \%$. The gains are largest, by far, in Japan and in developing Asia ( $+0.9 \%$ and $+0.8 \%$, respectively). This is due to the highly uneven crosssectoral structure of the protection of these areas: a rather low (actually, almost zero in Japan) protection in industry, while AVE tariffs are very high in agriculture. The liberalisation impact is thus concentrated in agriculture, translating in sizeable consumer gains. Corresponding tariff revenue losses are moderate (most of all in Japan), both because of the initial low level of imports in these sectors, and because of the rather high pricesensitivity of imports. Unsurprisingly, natural resources and land suffer a real loss in both areas, especially in Japan.

To a lesser extent, the EU and the rest of the world exhibit the same pattern of results. As Japan and developing Asia, these two regions lowered significantly their protection in agriculture, translating into higher gains, but also into a loss in land's real revenue. The mirror image is given by the impact on the US and the Cairns group. As exporters of agricultural goods, those regions experience a significant increase in the external demand 
addressed to its agricultural producers, and land's real reward is significantly increased. However the associated gains in welfare for both areas remain limited.

Table 5.1: Main macro-economic results, scenario (a) ("uniform")

(Variations in \%, compared to the reference, 14 years after the agreement)

\begin{tabular}{|c|c|c|c|c|c|c|c|}
\hline & EU-25 & USA & Japan & Cairns & $\begin{array}{r}\text { Dev'g } \\
\text { Asia } \\
\end{array}$ & $\mathrm{ACP}$ & Row \\
\hline Welfare & $0.4 \%$ & $0.2 \%$ & $0.9 \%$ & $0.3 \%$ & $0.8 \%$ & $0.4 \%$ & $0.5 \%$ \\
\hline GDP (volume) & $0.1 \%$ & $0.1 \%$ & $0.3 \%$ & $0.1 \%$ & $0.3 \%$ & $0.5 \%$ & $0.5 \%$ \\
\hline \multicolumn{8}{|l|}{ Prod'n factors real reward : } \\
\hline Unskilled labor & $0.3 \%$ & $0.2 \%$ & $0.4 \%$ & $0.4 \%$ & $0.8 \%$ & $1.2 \%$ & $0.5 \%$ \\
\hline Skilled labor & $0.3 \%$ & $0.2 \%$ & $0.6 \%$ & $0.3 \%$ & $1.2 \%$ & $1.2 \%$ & $0.8 \%$ \\
\hline Capital & $0.3 \%$ & $0.2 \%$ & $0.3 \%$ & $0.2 \%$ & $0.6 \%$ & $0.8 \%$ & $0.6 \%$ \\
\hline Natural resources & $-0.3 \%$ & $-0.2 \%$ & $-3.3 \%$ & $0.0 \%$ & $-1.0 \%$ & $1.1 \%$ & $2.2 \%$ \\
\hline Land & $-0.4 \%$ & $1.6 \%$ & $-5.0 \%$ & $2.8 \%$ & $-0.1 \%$ & $1.5 \%$ & $-1.7 \%$ \\
\hline Dual price index of utility & $0.3 \%$ & $0.0 \%$ & $-0.5 \%$ & $-0.3 \%$ & $-0.4 \%$ & $-1.4 \%$ & $0.2 \%$ \\
\hline Exports (volume) & $6.4 \%$ & $6.0 \%$ & $6.6 \%$ & $7.0 \%$ & $13.1 \%$ & $9.3 \%$ & $8.7 \%$ \\
\hline Imports (volume) & $7.4 \%$ & $5.2 \%$ & $7.6 \%$ & $6.8 \%$ & $12.6 \%$ & $7.8 \%$ & $8.8 \%$ \\
\hline Tariff revenue & $-19.1 \%$ & $-30.7 \%$ & $-2.6 \%$ & $-22.0 \%$ & $-18.6 \%$ & $-25.3 \%$ & $0.5 \%$ \\
\hline
\end{tabular}

Source: Authors' simulations using MIRAGE.

The situation of ACP countries appears as intermediate. The real reward of land and natural resources is increased, due to the leading role of the primary sector in this region's exports, but the real reward to labour is of the same order of magnitude. The most striking result for this region is probably the terms-of-trade loss. Indeed, this region has initially a rather high level of protection in general, and in industry in particular. The liberalisation effort conceded is therefore higher than for other areas. As a consequence, the trade balance equilibrium can only be reached at the price of a real depreciation, that is of a terms of trade deterioration. This is the reason why gains are moderate in ACP countries.

All in all welfare gains at the world level remain limited in this benchmark scenario, which does not come out as a surprise: tariff peaks are not severely affected by the linear formula used, whereas this is where sizeable gains have to expected. Hence, what is interesting is to compare this benchmark, with alternatives. First, there is a scenario excluding peaks from the tariff reduction that would make the Round a major failure to many observers.

Scenario (b) allows the specific impact of the cancellation of tariff peaks to be assessed, by comparison with scenario (a). Exempting tariff peaks from liberalisation drastically change the results (even though the order of magnitude remains small, in absolute terms). Broadly speaking, welfare gains and trade creation in volume are halved, and the variability of results across production factors and across countries is strongly reduced. As can be seen in table A2.1, trade creation falls sharply for some sectors, especially in agriculture. 
Table 5.2: Main macro-economic results, scenario (b) ("uniform, except peaks")

(Variations in \%, compared to the reference, 14 years after the agreement)

\begin{tabular}{lrrrrrrr} 
& & & \multicolumn{5}{c}{ Dev'g } \\
& EU-25 & USA & Japan & Cairns & Asia & ACP & Row \\
\cline { 2 - 9 } Welfare & $0.3 \%$ & $0.1 \%$ & $0.3 \%$ & $0.1 \%$ & $0.3 \%$ & $0.3 \%$ & $0.2 \%$ \\
GDP (volume) & $0.0 \%$ & $0.1 \%$ & $0.2 \%$ & $0.1 \%$ & $0.1 \%$ & $0.2 \%$ & $0.3 \%$ \\
Prod'n factors real reward : & & & & & & & \\
Unskilled labor & $0.1 \%$ & $0.1 \%$ & $0.2 \%$ & $0.2 \%$ & $0.3 \%$ & $0.5 \%$ & $0.3 \%$ \\
Skilled labor & $0.1 \%$ & $0.1 \%$ & $0.3 \%$ & $0.1 \%$ & $0.4 \%$ & $0.5 \%$ & $0.4 \%$ \\
Capital & $0.2 \%$ & $0.2 \%$ & $0.2 \%$ & $0.1 \%$ & $0.2 \%$ & $0.3 \%$ & $0.3 \%$ \\
Natural resources & $0.1 \%$ & $0.1 \%$ & $-3.3 \%$ & $0.2 \%$ & $-0.5 \%$ & $0.8 \%$ & $0.7 \%$ \\
Land & $-0.5 \%$ & $1.0 \%$ & $-1.4 \%$ & $1.5 \%$ & $-0.1 \%$ & $0.5 \%$ & $-1.0 \%$ \\
Dual price index of utility & $0.1 \%$ & $0.0 \%$ & $-0.2 \%$ & $0.0 \%$ & $-0.1 \%$ & $-0.6 \%$ & $0.1 \%$ \\
Exports (volume) & $4.3 \%$ & $4.5 \%$ & $-4.4 \%$ & $3.5 \%$ & $4.7 \%$ & $2.9 \%$ & $4.3 \%$ \\
Imports (volume) & $4.8 \%$ & $3.8 \%$ & $5.0 \%$ & $3.4 \%$ & $4.6 \%$ & $2.4 \%$ & $4.4 \%$ \\
Tariff revenue & $-13.3 \%$ & $-23.8 \%$ & $-10.5 \%$ & $-12.2 \%$ & $-7.3 \%$ & $-10.4 \%$ & $0.2 \%$
\end{tabular}

Source: Authors' simulations using MIRAGE.

The most important change, compared to scenario (a), is probably for Japan, where agriculture's liberalisation is very limited when tariff peaks are excluded. This reflects the very high and uneven level of protection of the Japanese agriculture. The decline in the real return to land is limited to $1.4 \%$ in Japan in this scenario, as compared to $5.0 \%$ in scenario (a). Hence the political economy sympathy for such scenario ${ }^{17}$. The slightly higher loss in real return to land in the EU in this scenario may appear as surprising at first glance, but this due to a more general phenomenon. Indeed, the EU enjoyed a significant gain in terms of trade in the first scenario, thanks to its strong position in industrial exports. Here, this terms of trade improvement almost vanishes, because of the lesser liberalisation of industrial sectors in other areas.

In contrast, scenario (c ) implements a truncated Swiss formula centred on tariff peaks as follows: up to the tariff peak, we simply apply the linear formula of scenario (a), while the coefficient of reduction increases in the initial tariff thereafter. Notice that the coefficient of the formula is different for agricultural products, leading to more limited tariff cuts. The formula guaranties that no tariff will be larger than $28 \%$ for non-agricultural products, as compared to $158 \%$ for agricultural ones (Figure 2). Starting from scenario (a), scenario (c) appears as the mirror image of scenario (b), since tariff peaks are evened out (see Table 5.3). Compared to scenario (a), trade creation is higher, by $10 \%$ to $30 \%$. In terms of

17 A bilateral sectoral survey of trade evolutions backs these points: whereas, in scenarios (a), (c) or (d),
some trade flows in the processed rice, dairy products or vegetable oils sectors saw the most important
increases, the list given in Table A 2.2 shows that for scenario (b), the order of magnitude of the most
importantly affected trade flows is ten times lower than in the other three scenarios and is found for
different sectors and partners. 
welfare, there are three regions of interest: Japan and Cairns because protection in agriculture is strongly eroded, Developing Asia because tariff peaks in labour intensive manufactures are compressed too. Hence Japan gains to its own liberalisation $(1.5 \%$ of welfare as compared to $0.9 \%$ ), additional gains being more limited for Cairns (one decimal point) and Developing Asia (3 decimal points). For the remaining regions, the gains are hardly changed. Of course, adopting a more severe formula for agricultural products would translate in magnified effects on trade and welfare.

Figure 2: Hypothetical tariff reductions in scenarios a and $\mathrm{c}$ for agricultural and non-agricultural products

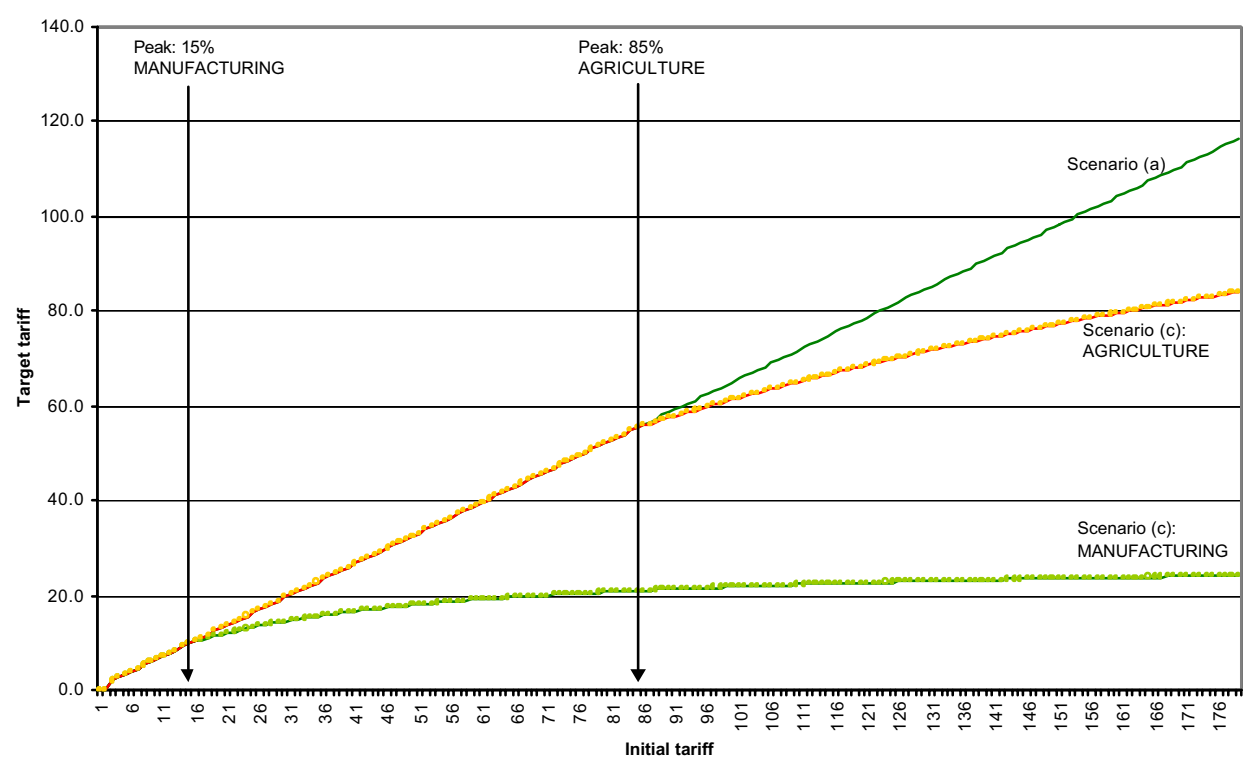

Once again, the Japanese agriculture appears as an outlier, as witnessed by the $11.6 \%$ loss in the land. The conflict of interest between agricultural and industrial producers, that is between landowners and capital-labour, is thus exacerbated in this scenario in Japan. Landowners in contrast suffer limited losses in the EU. This is even less clear in the US, where the whole gain as well as its distribution are hardly modified. The increased gain of landowners in the Cairns group is no surprise in this context, but it does not increase significantly welfare in this region. Finally, ACP countries still enjoy limited welfare gains. Welfare is not the only criterion to gauge the impact of a trade reform however. In developing countries, enhancing the real income of unskilled labour is certainly a valuable criterion. On this basis, scenario (c) translates in an increase in real reward for blue collars which is $50 \%$ higher than in scenario (a). And this gain is four times as large in scenario (c) than in scenario (b). Hence the importance of focusing the negotiation on a formula eroding tariff peaks. 


\section{Table 5.3: Main macro-economic results, scenario (c) ("evening out")}

(Variations in \%, compared to the reference, 14 years after the agreement)

\begin{tabular}{rrrrrrrr} 
& & & & & Dev'g & \\
& EU-25 & USA & Japan & Cairns & Asia & ACP & Row \\
\cline { 2 - 7 } Welfare & $0.4 \%$ & $0.2 \%$ & $1.5 \%$ & $0.4 \%$ & $1.1 \%$ & $0.4 \%$ & $0.8 \%$ \\
GDP (volume) & $0.1 \%$ & $0.2 \%$ & $0.4 \%$ & $0.1 \%$ & $0.4 \%$ & $0.4 \%$ & $0.6 \%$ \\
Prod'n factors real reward : & & & & & & & \\
Unskilled labor & $0.4 \%$ & $0.2 \%$ & $0.5 \%$ & $0.5 \%$ & $1.2 \%$ & $1.4 \%$ & $0.6 \%$ \\
Skilled labor & $0.5 \%$ & $0.2 \%$ & $0.9 \%$ & $0.5 \%$ & $1.3 \%$ & $2.0 \%$ & $0.9 \%$ \\
Capital & $0.5 \%$ & $0.2 \%$ & $0.4 \%$ & $0.2 \%$ & $0.7 \%$ & $1.0 \%$ & $0.8 \%$ \\
Natural resources & $-0.7 \%$ & $-0.5 \%$ & $-2.7 \%$ & $-0.5 \%$ & $-1.7 \%$ & $0.3 \%$ & $4.1 \%$ \\
Land & $-0.6 \%$ & $1.8 \%$ & $-11.6 \%$ & $3.7 \%$ & $0.4 \%$ & $1.4 \%$ & $-1.6 \%$ \\
Dual price index of utility & $0.2 \%$ & $0.0 \%$ & $-0.6 \%$ & $-0.4 \%$ & $0.0 \%$ & $-1.6 \%$ & $0.3 \%$ \\
Exports (volume) & $7.3 \%$ & $6.8 \%$ & $7.7 \%$ & $8.8 \%$ & $18.8 \%$ & $10.9 \%$ & $12.3 \%$ \\
Imports (volume) & $8.6 \%$ & $6.0 \%$ & $8.9 \%$ & $8.6 \%$ & $18.0 \%$ & $9.2 \%$ & $12.4 \%$ \\
Tariff revenue & $-25.6 \%$ & $-33.5 \%$ & $7.5 \%$ & $-28.6 \%$ & $-22.1 \%$ & $-32.8 \%$ & $0.8 \%$
\end{tabular}

Source: Authors' simulations using MIRAGE.

What would be the consequences of a smoother liberalisation for developing countries? To some extent, there were elements of the SDT in the previous scenarios, as far as developing countries were conceded to phase-in the tariff reduction over ten years, as compared to six for developed countries. Here, one goes a step further by conceding developing countries asymmetrical (relative) tariff reductions. The SDT is supposed to be conceded as an advantage; on the other hand, CGE modelling generally stresses that the bulk of welfare gains accrue as a result of a country's own trade liberalisation (Anderson et al, 2000; Francois, 2000). Here, according to the simulation of scenario (d), such a concession indeed gives raise to a slight redistribution of the gains from developed to developing countries. Given the trade balance constraint, the main channel through which the redistribution is obtained is the real exchange rate, and therefore the terms of trade. In scenario (d), their deterioration is far weaker in ACP countries, and developing Asia enjoys a significant gain. For the Cairns group, the welfare gain is unchanged, but its distribution is different. Land owners' gains are less high, while less deteriorated terms of trade is a source of gain. 
Table 5.4: Main macro-economic results, scenario (d) ("evening out, smoother for developing countries")

(Variations in \%, compared to the reference, 14 years after the agreement)

\begin{tabular}{|c|c|c|c|c|c|c|c|}
\hline & EU-25 & USA & Japan & Cairns & $\begin{array}{r}\text { Dev'g } \\
\text { Asia }\end{array}$ & ACP & Row \\
\hline Welfare & $0.3 \%$ & $0.1 \%$ & $1.3 \%$ & $0.4 \%$ & $0.9 \%$ & $0.3 \%$ & $0.7 \%$ \\
\hline GDP (volume) & $0.1 \%$ & $0.1 \%$ & $0.4 \%$ & $0.1 \%$ & $0.3 \%$ & $0.2 \%$ & $0.5 \%$ \\
\hline \multicolumn{8}{|l|}{ Prod'n factors real reward: } \\
\hline Unskilled labor & $0.4 \%$ & $0.1 \%$ & $0.5 \%$ & $0.4 \%$ & $0.9 \%$ & $1.0 \%$ & $0.4 \%$ \\
\hline Skilled labor & $0.5 \%$ & $0.2 \%$ & $0.9 \%$ & $0.5 \%$ & $0.9 \%$ & $1.2 \%$ & $0.6 \%$ \\
\hline Capital & $0.5 \%$ & $0.2 \%$ & $0.4 \%$ & $0.2 \%$ & $0.4 \%$ & $0.6 \%$ & $0.6 \%$ \\
\hline Natural resources & $-0.7 \%$ & $-0.4 \%$ & $-2.5 \%$ & $-0.7 \%$ & $-1.4 \%$ & $-0.6 \%$ & $3.4 \%$ \\
\hline Land & $-0.7 \%$ & $1.2 \%$ & $-11.5 \%$ & $2.7 \%$ & $0.7 \%$ & $1.3 \%$ & $-0.6 \%$ \\
\hline Dual price index of utility & $0.1 \%$ & $0.0 \%$ & $-0.2 \%$ & $-0.1 \%$ & $0.6 \%$ & $-0.8 \%$ & $0.3 \%$ \\
\hline Exports (volume) & $7.2 \%$ & $5.9 \%$ & $6.6 \%$ & $7.1 \%$ & $13.3 \%$ & $6.3 \%$ & $9.4 \%$ \\
\hline Imports (volume) & $8.2 \%$ & $5.2 \%$ & $7.7 \%$ & $6.9 \%$ & $12.8 \%$ & $5.4 \%$ & $9.5 \%$ \\
\hline Tariff revenue & $-25.9 \%$ & $-34.1 \%$ & $6.5 \%$ & $-18.3 \%$ & $-9.4 \%$ & $-19.6 \%$ & $0.7 \%$ \\
\hline
\end{tabular}

Source: Authors' simulations using MIRAGE.

\section{CONCLUSION}

The aim of this paper was to build a set of scenarios at the detailed level of nomenclature (on the basis of the most detailed information, as provided by MAcMaps), to evaluate accurately the impact of a choice of a formula. Hence, we focus on "modalities of negotiation to be agreed". Finally we assess their impact on world economies with MIRAGE, a CGE model conceived to study trade policies. This approach based on detailed information should provide a more accurate evaluation of the gains associated with trade liberalisation: working at too aggregated a level, or using biased aggregators, might minimise the gains (Martin et al., 2003).

The various scenarios are based on a systematic rule of evolution of the ad-valorem tariff equivalent of protection tabulated at the 6-digit level of the $\mathrm{SH}$ nomenclature, which is conditional to the initial level of the ad-valorem equivalent tariff. They cover two specific issues: tariffs peaks and special and differential treatment for developing countries.

Contrary to the popularised view that tariff protection has vanished, we stress there is still scope for liberalisation even in industrial sectors. But even more, as a result of evolutions in the protection instruments in agriculture following the Uruguay round, the issue of the treatment of tariffs peaks needs to be addressed.

Depending on the choice of a formula for market access in agricultural as well as nonagricultural products, gains to be expected from this central element of the DDA will vary by large. According to our simulations, trade and welfare gains are halved when excluding 
peaks from the negotiations. This does not come out as a surprise for trade economists; but the value added of this paper is to authorise tackling such issue in a CGEM, while relying on detailed information for tariffs. Previous work did in contrast rely on partial equilibrium approaches (Hoekman et al, 2002-a). Our results also stress the importance of such item of the negotiation for agriculture: the political economy of trade protection makes it hardly plausible to reach an agreement on an ambitious formula in agriculture, as a result of the very large redistribution of real income detrimental to land owners, especially in Japan. 


\section{REFERENCES}

Anderson, K., Francois J., Hertel T., Hoekman B., Martin. W. (2000), Potential Gains from Trade Reform in the New Millennium, GTAP conference paper.

Bouët A., Fontagné L., Mimouni M., Pichot X. (2001), Market Access Maps: A Bilateral and Disagreggated Measure of Market Access, Document de travail CEPII, 2001-18.

Bouët A., Fontagné L., Mimouni M., von Kirchbach F. (2002), Market Access Maps for GTAP: A Bilateral Measure of Merchandise Trade Protection. GTAP Resource Paper \#1045.

Bouët A., Bureau J.-C., Decreux Y., Jean S. (2003), Is Agricultural Liberalization Beneficial to Developing Countries, GTAP conference paper

Bchir M. H., Decreux Y., Guérin J.-L., Jean S. (2002), "MIRAGE, A CGE Model for Trade Policy Analysis", Working paper 2002-17, CEPII, Paris, available on www.cepii.fr.

FAPRI (2002), The Doha Round of the World Trade Organization: Appraising Further Liberalization of Agricultural Markets, Food and Agricultural Policy Research Institute, Iowa State University and University of Missouri, Columbia.

Fontagné L., Mimouni M. (2002), Development Round : A Formula Smoothing the Erosion of Preferences, Mimeo, ITC (UNCTAD-WTO).

Francois J. (2000), Assessing the Results of General Equilibrium Studies of Multilateral Trade Negotiations, UNCTAD, Policy Issues in International Trade and Commodities Study series (3), United Nations, Geneva.

Francois J.F., Martin W. (2003), Formula Approaches for Market Access Negotiations, The World Economy, 26(1): 1-28.

Francois J., van Meijl H., van Tongeren F. (2003), Economic Implications of Trade Liberalization under the Doha Round, mimeo, Erasmus University, Rotterdam.

Hoekman B., Ng F., Olarreaga M. (2002-a), Eliminating Excessive Tariffs on Exports of Least Developed Countries, World Bank Economic Review, 16(1): 1-21.

Hoekman B., Ng F., Olarreaga F. (2002-b), Reducing Agricultural Tariffs versus Domestic Support: What's More important for Developing Countries?, World Bank Policy Research Working Paper, \#2918.

Martin W., van der Mensbrugghe D., Manole V. (2003), Is the Devil in the Details?: Assessing the Welfare Implications of Agricultural and Non Agricultural Trade Reforms, mimeo, Word bank. 
Walkenhorst P., Dihel N., (2002), Bound Tariffs, Unused Protection, and Agricultural Trade Liberalisation, GTAP Conference Paper.

WTO (2002), Market Access: Unfinished Business- Post-Uruguay Round Inventory and Issues, Special Studies \#6, World Trade Organization. 


\section{ANNEX 1: AVERAGE AND STANDARD-DEVIATION OF TARIFFS IN THE BENCHMARK AND AS A RESULT OF EACH SCENARIO, FOR EACH REGION}

\section{Table A1: ACP countries}

$\begin{array}{cl}\text { No. Code } & \text { Description } \\ 1 \text { pdr } & \text { Paddy rice }\end{array}$

2 wht Wheat

3 gro Cereal grains nec

4 vaf Vegetables, fruit, nuts

5 osd Oil seeds

$6 \mathrm{cab}$ Sugar cane, sugar beet

7 ocr Crops nec

$8 \mathrm{ctl} \quad$ Cattle

9 oap Animal products nec

11 fsh Fishing

$12 \mathrm{cmt}$ Bovine meat products

$13 \mathrm{omt}$ Meat products nec

$14 \mathrm{vol}$ Vegetable oils and fats

15 mil Dairy products

16 pcr Processed rice

$17 \mathrm{sgr}$ Sugar

18 ofd Food products nec

19 bat Bevg. and tob. Prod.

$20 \mathrm{pfb} \quad$ Plant-based fibers

21 wol Wool

22 forest Forestry

23 prim Coal, oil, gas, min. nec

24 ias Ferrous metals

$25 \mathrm{nfm}$ Metals nec

26 tex Textiles

27 wap Wearing apparel

28 lea Leather products

29 lum Wood products

$30 \mathrm{nmm}$ Mineral products nec

$31 \mathrm{fmp}$ Metal products

32 omf Manufactures nec

33 ppp Paper prod., publishing

$34 \mathrm{pac} \quad$ Petroleum, coal prod.

35 crp Chem., rubber

$36 \mathrm{mvh}$ Motor vehicles and parts

37 otn Transport equipment nec

38 ele Electronic equipment

39 ome Mach'y \& equip't nec

41 Ser Services

\begin{tabular}{ccccc}
\multicolumn{5}{c}{ Trade-weighted average (across } \\
Initial & partners) & AVE & tariff \\
\cline { 2 - 5 } 0 & Scenario \\
0,18 & 0,12 & 0,12 & 0,12 & 0,14 \\
0,18 & 0,12 & 0,16 & 0,09 & 0,12 \\
0,11 & 0,07 & 0,08 & 0,07 & 0,09 \\
0,34 & 0,22 & 0,27 & 0,19 & 0,24 \\
0,04 & 0,03 & 0,03 & 0,03 & 0,03 \\
0,10 & 0,06 & 0,06 & 0,06 & 0,08 \\
0,16 & 0,10 & 0,11 & 0,10 & 0,13 \\
0,15 & 0,10 & 0,10 & 0,10 & 0,12 \\
0,11 & 0,07 & 0,07 & 0,07 & 0,09 \\
0,19 & 0,12 & 0,13 & 0,12 & 0,15 \\
0,20 & 0,13 & 0,13 & 0,13 & 0,16 \\
0,23 & 0,15 & 0,15 & 0,14 & 0,18 \\
0,17 & 0,11 & 0,11 & 0,11 & 0,14 \\
0,19 & 0,12 & 0,12 & 0,12 & 0,15 \\
0,26 & 0,17 & 0,19 & 0,15 & 0,19 \\
0,32 & 0,21 & 0,24 & 0,20 & 0,25 \\
0,18 & 0,12 & 0,12 & 0,11 & 0,14 \\
0,32 & 0,21 & 0,25 & 0,18 & 0,23 \\
0,11 & 0,07 & 0,09 & 0,07 & 0,09 \\
0,08 & 0,05 & 0,05 & 0,05 & 0,06 \\
0,15 & 0,10 & 0,10 & 0,10 & 0,12 \\
0,07 & 0,04 & 0,05 & 0,03 & 0,04 \\
0,10 & 0,06 & 0,08 & 0,05 & 0,06 \\
0,09 & 0,06 & 0,08 & 0,05 & 0,06 \\
0,15 & 0,09 & 0,14 & 0,07 & 0,10 \\
0,22 & 0,14 & 0,21 & 0,10 & 0,14 \\
0,15 & 0,09 & 0,14 & 0,08 & 0,10 \\
0,14 & 0,09 & 0,14 & 0,08 & 0,11 \\
0,14 & 0,09 & 0,13 & 0,07 & 0,09 \\
0,12 & 0,08 & 0,11 & 0,07 & 0,09 \\
0,18 & 0,12 & 0,17 & 0,10 & 0,13 \\
0,09 & 0,06 & 0,08 & 0,05 & 0,06 \\
0,15 & 0,10 & 0,13 & 0,07 & 0,09 \\
0,10 & 0,06 & 0,08 & 0,05 & 0,07 \\
0,14 & 0,09 & 0,12 & 0,08 & 0,10 \\
0,07 & 0,05 & 0,05 & 0,04 & 0,05 \\
0,09 & 0,06 & 0,07 & 0,05 & 0,06 \\
0,09 & 0,06 & 0,08 & 0,05 & 0,07 \\
0,04 & 0,02 & 0,04 & 0,04 & 0,04
\end{tabular}

Unweighted std-dev of AVE tariffs across partners

\begin{tabular}{ccccc} 
& \multicolumn{4}{c}{ Scenario } \\
\cline { 2 - 5 } Initial & (a) & (b) & (c) & (d) \\
0,45 & 0,48 & 0,46 & 0,51 & 0,49
\end{tabular}

$\begin{array}{lllll}0,08 & 0,11 & 0,08 & 0,14 & 0,11\end{array}$

$\begin{array}{llllll}0,03 & 0,06 & 0,05 & 0,07 & 0,05\end{array}$

$0,08 \quad 0,15 \quad 0,11 \quad 0,18 \quad 0,13$

$\begin{array}{llllll}0,02 & 0,03 & 0,03 & 0,03 & 0,03\end{array}$

$\begin{array}{llllll}0,04 & 0,05 & 0,05 & 0,05 & 0,04\end{array}$

$\begin{array}{llllll}0,05 & 0,08 & 0,07 & 0,08 & 0,06\end{array}$

$0,02 \quad 0,06 \quad 0,06 \quad 0,06 \quad 0,04$

$\begin{array}{lllll}0,01 & 0,04 & 0,04 & 0,04 & 0,03\end{array}$

$\begin{array}{lllll}0,02 & 0,07 & 0,07 & 0,07 & 0,04\end{array}$

$\begin{array}{lllll}0,05 & 0,09 & 0,09 & 0,09 & 0,07\end{array}$

$\begin{array}{lllll}0,03 & 0,08 & 0,08 & 0,09 & 0,06\end{array}$

$\begin{array}{llllll}0,04 & 0,07 & 0,07 & 0,07 & 0,06\end{array}$

$\begin{array}{lllll}0,02 & 0,07 & 0,07 & 0,07 & 0,04\end{array}$

$\begin{array}{llllll}0,04 & 0,09 & 0,08 & 0,10 & 0,07\end{array}$

$0,06 \quad 0,14 \quad 0,10 \quad 0,15 \quad 0,10$

$\begin{array}{lllll}0,01 & 0,07 & 0,06 & 0,07 & 0,04\end{array}$

$\begin{array}{lllll}0,11 & 0,17 & 0,13 & 0,20 & 0,15\end{array}$

$\begin{array}{llllll}0,03 & 0,05 & 0,04 & 0,05 & 0,04\end{array}$

$\begin{array}{llllll}0,02 & 0,03 & 0,03 & 0,03 & 0,02\end{array}$

$\begin{array}{llllll}0,05 & 0,07 & 0,07 & 0,07 & 0,06\end{array}$

$0,00 \quad 0,02 \quad 0,01 \quad 0,03 \quad 0,02$

$0,02 \quad 0,04 \quad 0,02 \quad 0,05 \quad 0,04$

$\begin{array}{lllll}0,01 & 0,03 & 0,02 & 0,04 & 0,03\end{array}$

$0,02 \quad 0,05 \quad 0,02 \quad 0,07 \quad 0,05$

$\begin{array}{llllll}0,03 & 0,08 & 0,03 & 0,12 & 0,08\end{array}$

$\begin{array}{lllll}0,01 & 0,05 & 0,02 & 0,06 & 0,04\end{array}$

$\begin{array}{lllll}0,01 & 0,05 & 0,02 & 0,07 & 0,04\end{array}$

$\begin{array}{lllll}0,03 & 0,06 & 0,04 & 0,08 & 0,06\end{array}$

$\begin{array}{llllll}0,01 & 0,05 & 0,02 & 0,06 & 0,04\end{array}$

$0,02 \quad 0,07 \quad 0,02 \quad 0,09 \quad 0,06$

$\begin{array}{lllll}0,01 & 0,03 & 0,01 & 0,04 & 0,03\end{array}$

$\begin{array}{lllll}0,03 & 0,06 & 0,04 & 0,08 & 0,06\end{array}$

$0,01 \quad 0,04 \quad 0,02 \quad 0,05 \quad 0,03$

$\begin{array}{llllll}0,01 & 0,05 & 0,02 & 0,06 & 0,04\end{array}$

$\begin{array}{llllll}0,02 & 0,03 & 0,02 & 0,03 & 0,03\end{array}$

$0,01 \quad 0,03 \quad 0,02 \quad 0,04 \quad 0,03$

$\begin{array}{lllll}0,01 & 0,04 & 0,02 & 0,05 & 0,03\end{array}$

$0,01 \quad 0,02 \quad 0,01 \quad 0,01 \quad 0,01$

Source: MAcMaps, authors' calculations. 


\section{Table A2: Cairns Group}

\begin{tabular}{|c|c|c|c|c|c|c|}
\hline \multirow[b]{2}{*}{ No. Code } & \multirow[b]{2}{*}{ Description } & \multirow[b]{2}{*}{ Initial } & \multicolumn{4}{|c|}{ 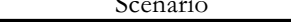 } \\
\hline & & & (a) & (b) & (c) & (d) \\
\hline $1 \mathrm{pdr}$ & Paddy rice & 0,12 & 0,08 & 0,11 & 0,08 & 0,10 \\
\hline 2 wht & Wheat & 0,17 & 0,10 & 0,13 & 0,10 & 0,12 \\
\hline 3 gro & Cereal grains nec & 0,20 & 0,13 & 0,15 & 0,12 & 0,15 \\
\hline 4 vaf & Vegetables, fruit, nuts & 0,02 & 0,02 & 0,02 & 0,02 & 0,02 \\
\hline 5 osd & Oil seeds & 0,09 & 0,06 & 0,07 & 0,05 & 0,07 \\
\hline $6 \mathrm{cab}$ & Sugar cane, sugar beet & 0,04 & 0,02 & 0,02 & 0,02 & 0,03 \\
\hline 7 ocr & Crops nec & 0,05 & 0,03 & 0,04 & 0,03 & 0,04 \\
\hline $8 \mathrm{ctl}$ & Cattle & 0,01 & 0,01 & 0,01 & 0,01 & 0,01 \\
\hline 9 oap & Animal products nec & 0,14 & 0,09 & 0,12 & 0,08 & 0,09 \\
\hline $11 \mathrm{fsh}$ & Fishing & 0,01 & 0,01 & 0,01 & 0,01 & 0,01 \\
\hline $12 \mathrm{cmt}$ & Bovine meat products & 0,09 & 0,06 & 0,06 & 0,05 & 0,06 \\
\hline $13 \mathrm{omt}$ & Meat products nec & 0,30 & 0,20 & 0,28 & 0,18 & 0,19 \\
\hline $14 \mathrm{vol}$ & Vegetable oils and fats & 0,09 & 0,06 & 0,06 & 0,05 & 0,06 \\
\hline 15 mil & Dairy products & 0,99 & 0,64 & 0,98 & 0,54 & 0,55 \\
\hline $16 \mathrm{pcr}$ & Processed rice & 0,13 & 0,09 & 0,11 & 0,08 & 0,10 \\
\hline $17 \mathrm{sgr}$ & Sugar & 0,14 & 0,09 & 0,12 & 0,09 & 0,10 \\
\hline 18 ofd & Food products nec & 0,11 & 0,07 & 0,08 & 0,07 & 0,08 \\
\hline 19 bat & Bevg. and tob. Prod. & 0,20 & 0,13 & 0,17 & 0,10 & 0,10 \\
\hline $20 \mathrm{pfb}$ & Plant-based fibers & 0,10 & 0,06 & 0,09 & 0,06 & 0,08 \\
\hline $21 \mathrm{wol}$ & Wool & 0,01 & 0,01 & 0,01 & 0,01 & 0,01 \\
\hline 22 forest & Forestry & 0,00 & 0,00 & 0,00 & 0,00 & 0,00 \\
\hline 23 prim & Coal, oil, gas, min. nec & 0,01 & 0,01 & 0,01 & 0,01 & 0,01 \\
\hline 24 ias & Ferrous metals & 0,06 & 0,04 & 0,05 & 0,04 & 0,04 \\
\hline $25 \mathrm{nfm}$ & Metals nec & 0,03 & 0,02 & 0,02 & 0,02 & 0,02 \\
\hline 26 tex & Textiles & 0,12 & 0,08 & 0,11 & 0,07 & 0,08 \\
\hline 27 wap & Wearing apparel & 0,19 & 0,12 & 0,18 & 0,10 & 0,11 \\
\hline 28 lea & Leather products & 0,11 & 0,07 & 0,08 & 0,07 & 0,07 \\
\hline 29 lum & Wood products & 0,05 & 0,04 & 0,05 & 0,03 & 0,04 \\
\hline $30 \mathrm{nmm}$ & Mineral products nec & 0,05 & 0,03 & 0,04 & 0,03 & 0,04 \\
\hline $31 \mathrm{fmp}$ & Metal products & 0,07 & 0,04 & 0,06 & 0,04 & 0,05 \\
\hline $32 \mathrm{omf}$ & Manufactures nec & 0,05 & 0,03 & 0,04 & 0,03 & 0,04 \\
\hline 33 ppp & Paper prod., publishing & 0,05 & 0,03 & 0,04 & 0,03 & 0,04 \\
\hline 34 pac & Petroleum, coal prod. & 0,13 & 0,08 & 0,12 & 0,05 & 0,06 \\
\hline $35 \mathrm{crp}$ & Chem., rubber & 0,07 & 0,04 & 0,05 & 0,04 & 0,05 \\
\hline $36 \mathrm{mvh}$ & Motor vehicles and parts & 0,13 & 0,08 & 0,12 & 0,06 & 0,08 \\
\hline 37 otn & Transport equipment nec & 0,03 & 0,02 & 0,02 & 0,02 & 0,02 \\
\hline 38 ele & Electronic equipment & 0,03 & 0,02 & 0,02 & 0,02 & 0,02 \\
\hline 39 ome & Mach'y \& equip't nec & 0,05 & 0,03 & 0,04 & 0,03 & 0,04 \\
\hline 41 Ser & Services & 0,00 & 0,00 & 0,00 & 0,00 & 0,00 \\
\hline
\end{tabular}

Unweighted std-dev of AVE tariffs across partners

\begin{tabular}{ccccc}
\hline & \multicolumn{4}{c}{ Scenario } \\
\cline { 2 - 5 } Initial & (a) & (b) & (c) & (d) \\
0,12 & 0,13 & 0,12 & 0,13 & 0,12 \\
0,08 & 0,12 & 0,11 & 0,12 & 0,11 \\
0,07 & 0,10 & 0,08 & 0,11 & 0,09 \\
0,01 & 0,02 & 0,02 & 0,02 & 0,02 \\
0,03 & 0,04 & 0,03 & 0,04 & 0,03 \\
0,09 & 0,09 & 0,09 & 0,09 & 0,09 \\
0,01 & 0,02 & 0,02 & 0,02 & 0,01 \\
0,02 & 0,02 & 0,02 & 0,02 & 0,02 \\
0,11 & 0,12 & 0,11 & 0,12 & 0,12 \\
0,02 & 0,02 & 0,02 & 0,02 & 0,02 \\
0,09 & 0,10 & 0,10 & 0,10 & 0,10 \\
0,24 & 0,31 & 0,24 & 0,33 & 0,33 \\
0,03 & 0,04 & 0,04 & 0,04 & 0,04 \\
0,35 & 0,43 & 0,35 & 0,47 & 0,47 \\
0,07 & 0,08 & 0,07 & 0,08 & 0,07 \\
0,06 & 0,09 & 0,07 & 0,09 & 0,08 \\
0,06 & 0,08 & 0,07 & 0,08 & 0,07 \\
0,06 & 0,10 & 0,07 & 0,13 & 0,12 \\
0,01 & 0,04 & 0,02 & 0,04 & 0,03 \\
0,01 & 0,01 & 0,01 & 0,01 & 0,01 \\
0,01 & 0,01 & 0,01 & 0,01 & 0,01 \\
0,01 & 0,01 & 0,01 & 0,01 & 0,01 \\
0,02 & 0,03 & 0,02 & 0,03 & 0,03 \\
0,01 & 0,02 & 0,02 & 0,02 & 0,02 \\
0,03 & 0,06 & 0,04 & 0,06 & 0,06 \\
0,02 & 0,07 & 0,02 & 0,09 & 0,08 \\
0,01 & 0,04 & 0,03 & 0,04 & 0,03 \\
0,03 & 0,04 & 0,03 & 0,04 & 0,03 \\
0,01 & 0,02 & 0,01 & 0,02 & 0,02 \\
0,01 & 0,03 & 0,02 & 0,03 & 0,02 \\
0,01 & 0,02 & 0,02 & 0,03 & 0,02 \\
0,02 & 0,03 & 0,03 & 0,03 & 0,03 \\
0,04 & 0,05 & 0,04 & 0,06 & 0,06 \\
0,01 & 0,03 & 0,02 & 0,03 & 0,02 \\
0,03 & 0,05 & 0,03 & 0,06 & 0,05 \\
0,03 & 0,04 & 0,03 & 0,04 & 0,04 \\
0,01 & 0,01 & 0,01 & 0,01 & 0,01 \\
0,01 & 0,02 & 0,01 & 0,02 & 0,01 \\
& & 0,01 & 0,01 & 0,01 \\
\hline
\end{tabular}

Source: MAcMaps, authors' calculations. 
Working Paper No 2003-12

Table A3: Developing Asia

\begin{tabular}{|c|c|c|c|c|c|c|c|c|c|c|c|}
\hline \multirow[b]{3}{*}{ No. Code } & \multirow[b]{3}{*}{ Description } & \multicolumn{5}{|c|}{$\begin{array}{c}\text { Trade-weighted average (across } \\
\text { partners) AVE tariff }\end{array}$} & \multicolumn{5}{|c|}{$\begin{array}{l}\text { Unweighted std-dev of AVE } \\
\text { tariffs across partners }\end{array}$} \\
\hline & & \multirow[b]{2}{*}{ Initial } & \multicolumn{4}{|c|}{ Scenario } & \multirow[b]{2}{*}{ Initial } & \multicolumn{4}{|c|}{ Scenario } \\
\hline & & & (a) & (b) & (c) & (d) & & (a) & (b) & (c) & (d) \\
\hline $1 \mathrm{pdr}$ & Paddy rice & 0,89 & 0,58 & 0,88 & 0,51 & 0,66 & 0,37 & 0,43 & 0,37 & 0,45 & 0,40 \\
\hline $2 \mathrm{wht}$ & Wheat & 0,90 & 0,59 & 0,90 & 0,52 & 0,68 & 0,34 & 0,41 & 0,34 & 0,43 & 0,38 \\
\hline 3 gro & Cereal grains nec & 0,54 & 0,35 & 0,53 & 0,33 & 0,41 & 0,19 & 0,24 & 0,19 & 0,26 & 0,21 \\
\hline 4 vaf & Vegetables, fruit, nuts & 0,05 & 0,03 & 0,03 & 0,03 & 0,04 & 0,03 & 0,03 & 0,03 & 0,03 & 0,03 \\
\hline 5 osd & Oil seeds & 0,84 & 0,55 & 0,84 & 0,49 & 0,63 & 0,36 & 0,38 & 0,36 & 0,39 & 0,37 \\
\hline $6 \mathrm{cab}$ & Sugar cane, sugar beet & 0,06 & 0,04 & 0,04 & 0,04 & 0,05 & 0,05 & 0,05 & 0,05 & 0,05 & 0,05 \\
\hline 7 ocr & Crops nec & 0,10 & 0,07 & 0,07 & 0,06 & 0,08 & 0,04 & 0,05 & 0,05 & 0,05 & 0,04 \\
\hline $8 \mathrm{ctl}$ & Cattle & 0,02 & 0,01 & 0,01 & 0,01 & 0,01 & 0,04 & 0,04 & 0,04 & 0,04 & 0,04 \\
\hline 9 oap & Animal products nec & 0,05 & 0,03 & 0,03 & 0,03 & 0,04 & 0,01 & 0,02 & 0,02 & 0,02 & 0,02 \\
\hline $11 \mathrm{fsh}$ & Fishing & 0,02 & 0,02 & 0,02 & 0,02 & 0,02 & 0,03 & 0,03 & 0,03 & 0,03 & 0,03 \\
\hline $12 \mathrm{cmt}$ & Bovine meat products & 0,06 & 0,04 & 0,04 & 0,04 & 0,05 & 0,12 & 0,12 & 0,12 & 0,12 & 0,12 \\
\hline $13 \mathrm{omt}$ & Meat products nec & 0,06 & 0,04 & 0,04 & 0,04 & 0,05 & 0,04 & 0,04 & 0,04 & 0,04 & 0,04 \\
\hline $14 \mathrm{vol}$ & Vegetable oils and fats & 0,21 & 0,14 & 0,19 & 0,13 & 0,16 & 0,09 & 0,11 & 0,09 & 0,11 & 0,10 \\
\hline 15 mil & Dairy products & 0,12 & 0,08 & 0,08 & 0,08 & 0,10 & 0,07 & 0,09 & 0,09 & 0,09 & 0,07 \\
\hline $16 \mathrm{pcr}$ & Processed rice & 0,56 & 0,36 & 0,56 & 0,32 & 0,42 & 0,25 & 0,29 & 0,25 & 0,31 & 0,27 \\
\hline 17 sgr & Sugar & 0,19 & 0,13 & 0,13 & 0,13 & 0,15 & 0,04 & 0,08 & 0,08 & 0,08 & 0,05 \\
\hline 18 ofd & Food products nec & 0,08 & 0,05 & 0,05 & 0,05 & 0,06 & 0,02 & 0,03 & 0,03 & 0,03 & 0,03 \\
\hline 19 bat & Bevg. and tob. Prod. & 0,31 & 0,20 & 0,26 & 0,18 & 0,20 & 0,12 & 0,14 & 0,13 & 0,15 & 0,14 \\
\hline $20 \mathrm{pfb}$ & Plant-based fibers & 0,02 & 0,01 & 0,01 & 0,01 & 0,01 & 0,00 & 0,01 & 0,01 & 0,01 & 0,00 \\
\hline 21 wol & Wool & 0,09 & 0,06 & 0,06 & 0,06 & 0,07 & 0,03 & 0,03 & 0,03 & 0,03 & 0,03 \\
\hline 22 forest & Forestry & 0,02 & 0,01 & 0,01 & 0,01 & 0,01 & 0,02 & 0,02 & 0,02 & 0,02 & 0,02 \\
\hline 23 prim & Coal, oil, gas, min. nec & 0,01 & 0,00 & 0,01 & 0,00 & 0,00 & 0,01 & 0,01 & 0,01 & 0,01 & 0,01 \\
\hline 24 ias & Ferrous metals & 0,06 & 0,04 & 0,04 & 0,03 & 0,04 & 0,02 & 0,02 & 0,02 & 0,03 & 0,02 \\
\hline $25 \mathrm{nfm}$ & Metals nec & 0,03 & 0,02 & 0,02 & 0,02 & 0,02 & 0,01 & 0,02 & 0,02 & 0,02 & 0,02 \\
\hline 26 tex & Textiles & 0,13 & 0,09 & 0,13 & 0,07 & 0,09 & 0,06 & 0,07 & 0,06 & 0,08 & 0,07 \\
\hline 27 wap & Wearing apparel & 0,10 & 0,06 & 0,10 & 0,04 & 0,06 & 0,11 & 0,12 & 0,11 & 0,12 & 0,12 \\
\hline 28 lea & Leather products & 0,06 & 0,04 & 0,05 & 0,03 & 0,04 & 0,03 & 0,03 & 0,03 & 0,04 & 0,03 \\
\hline 29 lum & Wood products & 0,03 & 0,02 & 0,02 & 0,02 & 0,02 & 0,02 & 0,03 & 0,02 & 0,03 & 0,03 \\
\hline $30 \mathrm{nmm}$ & Mineral products nec & 0,06 & 0,04 & 0,05 & 0,04 & 0,05 & 0,02 & 0,03 & 0,02 & 0,04 & 0,03 \\
\hline $31 \mathrm{fmp}$ & Metal products & 0,05 & 0,03 & 0,04 & 0,03 & 0,04 & 0,02 & 0,03 & 0,02 & 0,03 & 0,03 \\
\hline $32 \mathrm{omf}$ & Manufactures nec & 0,04 & 0,03 & 0,04 & 0,02 & 0,03 & 0,02 & 0,03 & 0,02 & 0,03 & 0,02 \\
\hline 33 ppp & Paper prod., publishing & 0,05 & 0,03 & 0,05 & 0,03 & 0,04 & 0,05 & 0,05 & 0,05 & 0,06 & 0,05 \\
\hline $34 \mathrm{pac}$ & Petroleum, coal prod. & 0,11 & 0,07 & 0,09 & 0,06 & 0,08 & 0,04 & 0,05 & 0,05 & 0,06 & 0,05 \\
\hline $35 \mathrm{crp}$ & Chem., rubber & 0,07 & 0,04 & 0,06 & 0,04 & 0,05 & 0,02 & 0,03 & 0,02 & 0,03 & 0,02 \\
\hline $36 \mathrm{mvh}$ & Motor vehicles and parts & 0,16 & 0,11 & 0,16 & 0,06 & 0,08 & 0,03 & 0,06 & 0,03 & 0,11 & 0,09 \\
\hline 37 otn & Transport equipment nec & 0,02 & 0,01 & 0,02 & 0,01 & 0,02 & 0,01 & 0,02 & 0,01 & 0,02 & 0,02 \\
\hline 38 ele & Electronic equipment & 0,10 & 0,06 & 0,08 & 0,06 & 0,07 & 0,03 & 0,05 & 0,03 & 0,05 & 0,04 \\
\hline 39 ome & Mach'y \& equip't nec & 0,07 & 0,04 & 0,06 & 0,04 & 0,05 & 0,01 & 0,03 & 0,02 & 0,03 & 0,02 \\
\hline 41 Ser & Services & 0,00 & 0,00 & 0,00 & 0,00 & 0,00 & 0,02 & 0,02 & 0,02 & 0,02 & 0,02 \\
\hline
\end{tabular}

Source: MAcMaps, authors' calculations. 
Table A4: 25-country European Union (EU-25)

\begin{tabular}{|c|c|c|c|c|c|c|c|c|c|c|c|}
\hline \multirow[b]{3}{*}{ No. Code } & \multirow[b]{3}{*}{ Description } & \multicolumn{5}{|c|}{$\begin{array}{c}\text { Trade-weighted average (across } \\
\text { partners) AVE tariff }\end{array}$} & \multicolumn{5}{|c|}{$\begin{array}{l}\text { Unweighted std-dev of AVE } \\
\text { tariffs across partners }\end{array}$} \\
\hline & & \multirow[b]{2}{*}{ Initial } & \multicolumn{4}{|c|}{ Scenario } & \multirow[b]{2}{*}{ Initial } & \multicolumn{4}{|c|}{ Scenario } \\
\hline & & & (a) & (b) & (c) & (d) & & (a) & (b) & (c) & (d) \\
\hline $1 \mathrm{pdr}$ & Paddy rice & 0,57 & 0,37 & 0,43 & 0,32 & 0,32 & 0,22 & 0,30 & 0,26 & 0,32 & 0,32 \\
\hline 2 wht & Wheat & 0,43 & 0,28 & 0,37 & 0,26 & 0,26 & 0,21 & 0,27 & 0,22 & 0,30 & 0,30 \\
\hline 3 gro & Cereal grains nec & 0,51 & 0,33 & 0,44 & 0,32 & 0,32 & 0,12 & 0,19 & 0,14 & 0,20 & 0,20 \\
\hline 4 vaf & Vegetables, fruit, nuts & 0,25 & 0,16 & 0,18 & 0,16 & 0,16 & 0,07 & 0,11 & 0,09 & 0,11 & 0,11 \\
\hline 5 osd & Oil seeds & 0,29 & 0,19 & 0,19 & 0,19 & 0,19 & 0,08 & 0,12 & 0,12 & 0,12 & 0,12 \\
\hline $6 \mathrm{cab}$ & Sugar cane, sugar beet & 0,19 & 0,12 & 0,12 & 0,12 & 0,12 & 0,11 & 0,12 & 0,12 & 0,12 & 0,12 \\
\hline 7 ocr & Crops nec & 0,10 & 0,06 & 0,07 & 0,06 & 0,06 & 0,04 & 0,05 & 0,05 & 0,05 & 0,05 \\
\hline $8 \mathrm{ctl}$ & Cattle & 0,53 & 0,34 & 0,42 & 0,33 & 0,33 & 0,19 & 0,26 & 0,22 & 0,28 & 0,28 \\
\hline 9 oap & Animal products nec & 0,09 & 0,06 & 0,07 & 0,05 & 0,05 & 0,04 & 0,05 & 0,05 & 0,05 & 0,05 \\
\hline $11 \mathrm{fsh}$ & Fishing & 0,06 & 0,04 & 0,04 & 0,04 & 0,04 & 0,03 & 0,04 & 0,04 & 0,04 & 0,04 \\
\hline $12 \mathrm{cmt}$ & Bovine meat products & 1,23 & 0,80 & 1,16 & 0,62 & 0,62 & 0,77 & 0,99 & 0,77 & 1,29 & 1,29 \\
\hline $13 \mathrm{omt}$ & Meat products nec & 0,49 & 0,32 & 0,40 & 0,29 & 0,29 & 0,05 & 0,18 & 0,10 & 0,22 & 0,22 \\
\hline $14 \mathrm{vol}$ & Vegetable oils and fats & 0,40 & 0,26 & 0,35 & 0,22 & 0,22 & 0,10 & 0,15 & 0,11 & 0,17 & 0,17 \\
\hline $15 \mathrm{mil}$ & Dairy products & 0,80 & 0,52 & 0,73 & 0,48 & 0,48 & 0,09 & 0,27 & 0,14 & 0,31 & 0,31 \\
\hline $16 \mathrm{pcr}$ & Processed rice & 0,56 & 0,36 & 0,44 & 0,35 & 0,35 & 0,15 & 0,24 & 0,18 & 0,25 & 0,25 \\
\hline $17 \mathrm{sgr}$ & Sugar & 0,94 & 0,61 & 0,82 & 0,51 & 0,51 & 0,27 & 0,44 & 0,29 & 0,56 & 0,56 \\
\hline 18 ofd & Food products nec & 0,15 & 0,09 & 0,10 & 0,09 & 0,09 & 0,06 & 0,08 & 0,07 & 0,08 & 0,08 \\
\hline 19 bat & Bevg. and tob. Prod. & 0,15 & 0,10 & 0,11 & 0,08 & 0,08 & 0,10 & 0,13 & 0,11 & 0,14 & 0,14 \\
\hline $20 \mathrm{pfb}$ & Plant-based fibers & 0,00 & 0,00 & 0,00 & 0,00 & 0,00 & 0,00 & 0,00 & 0,00 & 0,00 & 0,00 \\
\hline 21 wol & Wool & 0,02 & 0,01 & 0,01 & 0,01 & 0,01 & 0,01 & 0,01 & 0,01 & 0,01 & 0,01 \\
\hline 22 forest & Forestry & 0,01 & 0,00 & 0,00 & 0,00 & 0,00 & 0,00 & 0,01 & 0,01 & 0,01 & 0,01 \\
\hline 23 prim & Coal, oil, gas, min. nec & 0,07 & 0,05 & 0,07 & 0,01 & 0,01 & 0,03 & 0,03 & 0,03 & 0,04 & 0,04 \\
\hline 24 ias & Ferrous metals & 0,04 & 0,02 & 0,03 & 0,02 & 0,02 & 0,01 & 0,02 & 0,02 & 0,02 & 0,02 \\
\hline $25 \mathrm{nfm}$ & Metals nec & 0,04 & 0,02 & 0,02 & 0,02 & 0,02 & 0,02 & 0,02 & 0,02 & 0,02 & 0,02 \\
\hline 26 tex & Textiles & 0,09 & 0,06 & 0,07 & 0,06 & 0,06 & 0,03 & 0,04 & 0,04 & 0,04 & 0,04 \\
\hline 27 wap & Wearing apparel & 0,10 & 0,06 & 0,07 & 0,06 & 0,06 & 0,05 & 0,06 & 0,05 & 0,06 & 0,06 \\
\hline 28 lea & Leather products & 0,08 & 0,05 & 0,06 & 0,05 & 0,05 & 0,03 & 0,04 & 0,03 & 0,04 & 0,04 \\
\hline 29 lum & Wood products & 0,02 & 0,01 & 0,01 & 0,01 & 0,01 & 0,02 & 0,02 & 0,02 & 0,02 & 0,02 \\
\hline $30 \mathrm{nmm}$ & Mineral products nec & 0,04 & 0,03 & 0,03 & 0,03 & 0,03 & 0,02 & 0,02 & 0,02 & 0,02 & 0,02 \\
\hline $31 \mathrm{fmp}$ & Metal products & 0,06 & 0,04 & 0,04 & 0,03 & 0,03 & 0,02 & 0,03 & 0,02 & 0,03 & 0,03 \\
\hline $32 \mathrm{omf}$ & Manufactures nec & 0,04 & 0,03 & 0,03 & 0,02 & 0,02 & 0,01 & 0,02 & 0,01 & 0,02 & 0,02 \\
\hline 33 ppp & Paper prod., publishing & 0,04 & 0,02 & 0,02 & 0,02 & 0,02 & 0,01 & 0,02 & 0,02 & 0,02 & 0,02 \\
\hline $34 \mathrm{pac}$ & Petroleum, coal prod. & 0,02 & 0,02 & 0,02 & 0,01 & 0,01 & 0,01 & 0,01 & 0,01 & 0,01 & 0,01 \\
\hline $35 \mathrm{crp}$ & Chem., rubber & 0,05 & 0,03 & 0,04 & 0,03 & 0,03 & 0,02 & 0,02 & 0,02 & 0,02 & 0,02 \\
\hline $36 \mathrm{mvh}$ & Motor vehicles and parts & 0,08 & 0,05 & 0,06 & 0,05 & 0,05 & 0,03 & 0,04 & 0,04 & 0,04 & 0,04 \\
\hline 37 otn & Transport equipment nec & 0,02 & 0,01 & 0,02 & 0,01 & 0,01 & 0,03 & 0,04 & 0,03 & 0,04 & 0,04 \\
\hline 38 ele & Electronic equipment & 0,03 & 0,02 & 0,02 & 0,02 & 0,02 & 0,01 & 0,01 & 0,01 & 0,01 & 0,01 \\
\hline 39 ome & Mach'y \& equip't nec & 0,03 & 0,02 & 0,02 & 0,02 & 0,02 & 0,01 & 0,01 & 0,01 & 0,01 & 0,01 \\
\hline 41 Ser & Services & 0,00 & 0,00 & 0,00 & 0,00 & 0,00 & 0,01 & 0,01 & 0,01 & 0,01 & 0,01 \\
\hline
\end{tabular}

Source: MAcMaps, authors' calculations. 
Table A5: Japan

\begin{tabular}{|c|c|c|c|c|c|c|c|c|c|c|c|}
\hline \multirow[b]{3}{*}{ No. Code } & \multirow[b]{3}{*}{ Description } & \multicolumn{5}{|c|}{$\begin{array}{c}\text { Trade-weighted average (across } \\
\text { partners) AVE tariff }\end{array}$} & \multicolumn{5}{|c|}{$\begin{array}{l}\text { Unweighted std-dev of AVE } \\
\text { tariffs across partners }\end{array}$} \\
\hline & & \multirow[b]{2}{*}{ Initial } & \multicolumn{4}{|c|}{ Scenario } & \multirow[b]{2}{*}{ Initial } & \multicolumn{4}{|c|}{ Scenario } \\
\hline & & & (a) & (b) & (c) & (d) & & (a) & (b) & (c) & (d) \\
\hline $1 \mathrm{pdr}$ & Paddy rice & 1,56 & 1,02 & 1,56 & 0,61 & 0,61 & 0,97 & 1,20 & 0,97 & 1,56 & 1,56 \\
\hline 2 wht & Wheat & 1,43 & 0,93 & 1,43 & 0,75 & 0,75 & 0,85 & 1,15 & 0,85 & 1,57 & 1,57 \\
\hline 3 gro & Cereal grains nec & 0,37 & 0,24 & 0,25 & 0,23 & 0,23 & 0,32 & 0,37 & 0,33 & 0,42 & 0,42 \\
\hline 4 vaf & Vegetables, fruit, nuts & 0,16 & 0,11 & 0,14 & 0,09 & 0,09 & 0,07 & 0,09 & 0,08 & 0,10 & 0,10 \\
\hline 5 osd & Oil seeds & 0,45 & 0,29 & 0,45 & 0,17 & 0,17 & 1,14 & 1,16 & 1,14 & 1,24 & 1,24 \\
\hline $6 \mathrm{cab}$ & Sugar cane, sugar beet & & & & & & 0,00 & 0,00 & 0,00 & 0,00 & 0,00 \\
\hline 7 ocr & Crops nec & 0,01 & 0,00 & 0,00 & 0,00 & 0,00 & 0,00 & 0,01 & 0,01 & 0,01 & 0,01 \\
\hline $8 \mathrm{ctl}$ & Cattle & 0,24 & 0,16 & 0,18 & 0,15 & 0,15 & 0,32 & 0,35 & 0,33 & 0,35 & 0,35 \\
\hline 9 oap & Animal products nec & 0,04 & 0,02 & 0,03 & 0,02 & 0,02 & 0,02 & 0,02 & 0,02 & 0,02 & 0,02 \\
\hline $11 \mathrm{fsh}$ & Fishing & 0,05 & 0,03 & 0,03 & 0,03 & 0,03 & 0,01 & 0,02 & 0,02 & 0,02 & 0,02 \\
\hline $12 \mathrm{cmt}$ & Bovine meat products & 0,46 & 0,30 & 0,30 & 0,30 & 0,30 & 0,04 & 0,16 & 0,15 & 0,16 & 0,16 \\
\hline $13 \mathrm{omt}$ & Meat products nec & 0,38 & 0,24 & 0,29 & 0,23 & 0,23 & 0,14 & 0,18 & 0,16 & 0,19 & 0,19 \\
\hline $14 \mathrm{vol}$ & Vegetable oils and fats & 0,05 & 0,03 & 0,03 & 0,03 & 0,03 & 0,02 & 0,03 & 0,03 & 0,03 & 0,03 \\
\hline 15 mil & Dairy products & 1,17 & 0,76 & 1,13 & 0,57 & 0,57 & 0,64 & 0,83 & 0,64 & 1,07 & 1,07 \\
\hline $16 \mathrm{pcr}$ & Processed rice & 1,81 & 1,18 & 1,81 & 0,65 & 0,65 & 1,10 & 1,29 & 1,10 & 1,62 & 1,62 \\
\hline $17 \operatorname{sgr}$ & Sugar & 1,96 & 1,28 & 1,92 & 0,77 & 0,77 & 0,44 & 0,68 & 0,45 & 0,90 & 0,90 \\
\hline 18 ofd & Food products nec & 0,18 & 0,12 & 0,12 & 0,11 & 0,11 & 0,07 & 0,09 & 0,09 & 0,09 & 0,09 \\
\hline 19 bat & Bevg. and tob. Prod. & 0,19 & 0,13 & 0,13 & 0,13 & 0,13 & 0,04 & 0,09 & 0,09 & 0,09 & 0,09 \\
\hline $20 \mathrm{pfb}$ & Plant-based fibers & & & & & & 0,00 & 0,00 & 0,00 & 0,00 & 0,00 \\
\hline 21 wol & Wool & 0,00 & 0,00 & 0,00 & 0,00 & 0,00 & 0,01 & 0,01 & 0,01 & 0,01 & 0,01 \\
\hline 22 forest & Forestry & 0,00 & 0,00 & 0,00 & 0,00 & 0,00 & 0,00 & 0,00 & 0,00 & 0,00 & 0,00 \\
\hline 23 prim & Coal, oil, gas, min. nec & 0,00 & 0,00 & 0,00 & 0,00 & 0,00 & 0,00 & 0,00 & 0,00 & 0,00 & 0,00 \\
\hline 24 ias & Ferrous metals & 0,01 & 0,00 & 0,00 & 0,00 & 0,00 & 0,01 & 0,01 & 0,01 & 0,01 & 0,01 \\
\hline $25 \mathrm{nfm}$ & Metals nec & 0,01 & 0,01 & 0,01 & 0,01 & 0,01 & 0,01 & 0,01 & 0,01 & 0,01 & 0,01 \\
\hline 26 tex & Textiles & 0,07 & 0,05 & 0,05 & 0,04 & 0,04 & 0,01 & 0,03 & 0,02 & 0,03 & 0,03 \\
\hline 27 wap & Wearing apparel & 0,07 & 0,05 & 0,05 & 0,05 & 0,05 & 0,03 & 0,04 & 0,04 & 0,04 & 0,04 \\
\hline 28 lea & Leather products & 0,17 & 0,11 & 0,17 & 0,10 & 0,10 & 0,05 & 0,08 & 0,05 & 0,09 & 0,09 \\
\hline 29 lum & Wood products & 0,01 & 0,00 & 0,00 & 0,00 & 0,00 & 0,00 & 0,01 & 0,01 & 0,01 & 0,01 \\
\hline $30 \mathrm{nmm}$ & Mineral products nec & 0,01 & 0,00 & 0,00 & 0,00 & 0,00 & 0,01 & 0,01 & 0,01 & 0,01 & 0,01 \\
\hline $31 \mathrm{fmp}$ & Metal products & 0,01 & 0,00 & 0,00 & 0,00 & 0,00 & 0,00 & 0,01 & 0,01 & 0,01 & 0,01 \\
\hline $32 \mathrm{omf}$ & Manufactures nec & 0,01 & 0,01 & 0,01 & 0,01 & 0,01 & 0,01 & 0,01 & 0,01 & 0,01 & 0,01 \\
\hline 33 ppp & Paper prod., publishing & 0,01 & 0,01 & 0,01 & 0,01 & 0,01 & 0,01 & 0,01 & 0,01 & 0,01 & 0,01 \\
\hline $34 \mathrm{pac}$ & Petroleum, coal prod. & 0,05 & 0,03 & 0,03 & 0,03 & 0,03 & 0,02 & 0,02 & 0,02 & 0,02 & 0,02 \\
\hline $35 \mathrm{crp}$ & Chem., rubber & 0,01 & 0,01 & 0,01 & 0,01 & 0,01 & 0,01 & 0,01 & 0,01 & 0,01 & 0,01 \\
\hline $36 \mathrm{mvh}$ & Motor vehicles and parts & & & & & & 0,00 & 0,00 & 0,00 & 0,00 & 0,00 \\
\hline 37 otn & Transport equipment nec & & & & & & 0,00 & 0,00 & 0,00 & 0,00 & 0,00 \\
\hline 38 ele & Electronic equipment & & & & & & 0,00 & 0,00 & 0,00 & 0,00 & 0,00 \\
\hline 39 ome & Mach'y \& equip't nec & 0,00 & 0,00 & 0,00 & 0,00 & 0,00 & 0,00 & 0,00 & 0,00 & 0,00 & 0,00 \\
\hline 41 Ser & Services & & & & & & 0,00 & 0,00 & 0,00 & 0,00 & 0,00 \\
\hline
\end{tabular}

Source: MAcMaps, authors' calculations.

Note: Blanks refer to nil values. 
Table A6: United States

\begin{tabular}{|c|c|c|c|c|c|c|c|c|c|c|c|}
\hline \multirow[b]{2}{*}{ No. Code } & \multirow[b]{2}{*}{ Description } & \multirow[b]{2}{*}{ Initial } & \multicolumn{4}{|c|}{ Scenario } & \multirow[b]{2}{*}{ Initial } & \multicolumn{4}{|c|}{ Scenario } \\
\hline & & & (a) & (b) & (c) & (d) & & (a) & (b) & (c) & (d) \\
\hline 1 pdr & Paddy rice & 0,02 & 0,00 & 0,00 & 0,00 & 0,00 & 0,02 & 0,02 & 0,02 & 0,02 & 0,02 \\
\hline 2 wht & Wheat & 0,01 & 0,01 & 0,01 & 0,01 & 0,01 & 0,01 & 0,01 & 0,01 & 0,01 & 0,01 \\
\hline 3 gro & Cereal grains nec & 0,01 & 0,00 & 0,00 & 0,00 & 0,00 & 0,01 & 0,01 & 0,01 & 0,01 & 0,01 \\
\hline 4 vaf & Vegetables, fruit, nuts & 0,02 & 0,01 & 0,01 & 0,01 & 0,01 & 0,04 & 0,04 & 0,04 & 0,04 & 0,04 \\
\hline 5 osd & Oil seeds & 0,10 & 0,07 & 0,07 & 0,07 & 0,07 & 0,12 & 0,13 & 0,13 & 0,13 & 0,13 \\
\hline $6 \mathrm{cab}$ & Sugar cane, sugar beet & 0,01 & & & & & 0,01 & 0,01 & 0,01 & 0,01 & 0,01 \\
\hline 7 ocr & Crops nec & 0,30 & 0,19 & 0,19 & 0,19 & 0,19 & 0,10 & 0,13 & 0,13 & 0,13 & 0,13 \\
\hline $8 \mathrm{ctl}$ & Cattle & 0,00 & 0,00 & 0,00 & 0,00 & 0,00 & 0,00 & 0,00 & 0,00 & 0,00 & 0,00 \\
\hline 9 oap & Animal products nec & 0,00 & 0,00 & 0,00 & 0,00 & 0,00 & 0,00 & 0,00 & 0,00 & 0,00 & 0,00 \\
\hline $11 \mathrm{fsh}$ & Fishing & 0,00 & 0,00 & 0,00 & 0,00 & 0,00 & 0,00 & 0,00 & 0,00 & 0,00 & 0,00 \\
\hline $12 \mathrm{cmt}$ & Bovine meat products & 0,12 & 0,08 & 0,08 & 0,08 & 0,08 & 0,02 & 0,04 & 0,04 & 0,04 & 0,04 \\
\hline $13 \mathrm{omt}$ & Meat products nec & 0,02 & 0,02 & 0,02 & 0,02 & 0,02 & 0,02 & 0,02 & 0,02 & 0,02 & 0,02 \\
\hline $14 \mathrm{vol}$ & Vegetable oils and fats & 0,03 & 0,02 & 0,02 & 0,02 & 0,02 & 0,01 & 0,02 & 0,02 & 0,02 & 0,02 \\
\hline 15 mil & Dairy products & 0,30 & 0,20 & 0,20 & 0,20 & 0,20 & 0,05 & 0,11 & 0,11 & 0,11 & 0,11 \\
\hline $16 \mathrm{pcr}$ & Processed rice & 0,04 & 0,02 & 0,02 & 0,02 & 0,02 & 0,02 & 0,03 & 0,03 & 0,03 & 0,03 \\
\hline $17 \mathrm{sgr}$ & Sugar & 0,28 & 0,18 & 0,18 & 0,18 & 0,18 & 0,13 & 0,15 & 0,15 & 0,15 & 0,15 \\
\hline 18 ofd & Food products nec & 0,12 & 0,08 & 0,08 & 0,08 & 0,08 & 0,04 & 0,05 & 0,05 & 0,05 & 0,05 \\
\hline 19 bat & Bevg. and tob. Prod. & 0,04 & 0,03 & 0,03 & 0,03 & 0,03 & 0,02 & 0,02 & 0,02 & 0,02 & 0,02 \\
\hline $20 \mathrm{pfb}$ & Plant-based fibers & 0,10 & 0,07 & 0,07 & 0,07 & 0,07 & 0,01 & 0,04 & 0,04 & 0,04 & 0,04 \\
\hline 21 wol & Wool & 0,00 & 0,00 & 0,00 & 0,00 & 0,00 & 0,01 & 0,01 & 0,01 & 0,01 & 0,01 \\
\hline 22 forest & Forestry & 0,00 & 0,00 & 0,00 & 0,00 & 0,00 & 0,00 & 0,00 & 0,00 & 0,00 & 0,00 \\
\hline 23 prim & Coal, oil, gas, min. nec & 0,00 & 0,00 & 0,00 & 0,00 & 0,00 & 0,01 & 0,01 & 0,01 & 0,01 & 0,01 \\
\hline 24 ias & Ferrous metals & 0,03 & 0,02 & 0,02 & 0,02 & 0,02 & 0,01 & 0,02 & 0,02 & 0,02 & 0,02 \\
\hline $25 \mathrm{nfm}$ & Metals nec & 0,01 & 0,00 & 0,00 & 0,00 & 0,00 & 0,01 & 0,02 & 0,02 & 0,02 & 0,02 \\
\hline 26 tex & Textiles & 0,10 & 0,06 & 0,08 & 0,06 & 0,06 & 0,01 & 0,04 & 0,02 & 0,04 & 0,04 \\
\hline 27 wap & Wearing apparel & 0,11 & 0,07 & 0,09 & 0,07 & 0,07 & 0,01 & 0,04 & 0,03 & 0,04 & 0,04 \\
\hline 28 lea & Leather products & 0,14 & 0,09 & 0,12 & 0,08 & 0,08 & 0,02 & 0,05 & 0,03 & 0,06 & 0,06 \\
\hline 29 lum & Wood products & 0,01 & 0,01 & 0,01 & 0,01 & 0,01 & 0,01 & 0,01 & 0,01 & 0,01 & 0,01 \\
\hline $30 \mathrm{nmm}$ & Mineral products nec & 0,05 & 0,03 & 0,04 & 0,03 & 0,03 & 0,02 & 0,03 & 0,03 & 0,03 & 0,03 \\
\hline $31 \mathrm{fmp}$ & Metal products & 0,03 & 0,02 & 0,03 & 0,02 & 0,02 & 0,02 & 0,02 & 0,02 & 0,02 & 0,02 \\
\hline $32 \mathrm{omf}$ & Manufactures nec & 0,02 & 0,01 & 0,01 & 0,01 & 0,01 & 0,01 & 0,01 & 0,01 & 0,01 & 0,01 \\
\hline 33 ppp & Paper prod., publishing & 0,00 & 0,00 & 0,00 & 0,00 & 0,00 & 0,00 & 0,01 & 0,01 & 0,01 & 0,01 \\
\hline $34 \mathrm{pac}$ & Petroleum, coal prod. & 0,01 & 0,01 & 0,01 & 0,01 & 0,01 & 0,01 & 0,01 & 0,01 & 0,01 & 0,01 \\
\hline 35 crp & Chem., rubber & 0,04 & 0,02 & 0,03 & 0,02 & 0,02 & 0,01 & 0,02 & 0,02 & 0,02 & 0,02 \\
\hline $36 \mathrm{mvh}$ & Motor vehicles and parts & 0,01 & 0,00 & 0,00 & 0,00 & 0,00 & 0,01 & 0,01 & 0,01 & 0,01 & 0,01 \\
\hline 37 otn & Transport equipment nec & 0,01 & 0,01 & 0,01 & 0,01 & 0,01 & 0,02 & 0,02 & 0,02 & 0,02 & 0,02 \\
\hline 38 ele & Electronic equipment & 0,01 & 0,00 & 0,00 & 0,00 & 0,00 & 0,00 & 0,00 & 0,00 & 0,00 & 0,00 \\
\hline 39 ome & Mach'y \& equip't nec & 0,01 & 0,01 & 0,01 & 0,01 & 0,01 & 0,01 & 0,01 & 0,01 & 0,01 & 0,01 \\
\hline 41 Ser & Services & & & & & & 0,00 & 0,00 & 0,00 & 0,00 & 0,00 \\
\hline
\end{tabular}

Note: Blanks refer to nil values.

Source: MAcMaps, authors' calculations. 
Working Paper No 2003-12

Table A7: Rest of the World

\begin{tabular}{|c|c|}
\hline No. Code & Description \\
\hline $1 \mathrm{pdr}$ & Paddy rice \\
\hline 2 wht & Wheat \\
\hline 3 gro & Cereal grains nec \\
\hline 4 vaf & Vegetables, fruit, nuts \\
\hline 5 osd & Oil seeds \\
\hline $6 \mathrm{cab}$ & Sugar cane, sugar beet \\
\hline 7 ocr & Crops nec \\
\hline $8 \mathrm{ctl}$ & Cattle \\
\hline 9 oap & Animal products nec \\
\hline $11 \mathrm{fsh}$ & Fishing \\
\hline $12 \mathrm{cmt}$ & Bovine meat products \\
\hline $13 \mathrm{omt}$ & Meat products nec \\
\hline $14 \mathrm{vol}$ & Vegetable oils and fats \\
\hline 15 mil & Dairy products \\
\hline $16 \mathrm{pcr}$ & Processed rice \\
\hline $17 \mathrm{sgr}$ & Sugar \\
\hline 18 ofd & Food products nec \\
\hline 19 bat & Bevg. and tob. Prod. \\
\hline $20 \mathrm{pfb}$ & Plant-based fibers \\
\hline 21 wol & Wool \\
\hline 22 forest & Forestry \\
\hline 23 prim & Coal, oil, gas, min. nec \\
\hline 24 ias & Ferrous metals \\
\hline $25 \mathrm{nfm}$ & Metals nec \\
\hline 26 tex & Textiles \\
\hline 27 wap & Wearing apparel \\
\hline 28 lea & Leather products \\
\hline 29 lum & Wood products \\
\hline $30 \mathrm{nmm}$ & Mineral products nec \\
\hline $31 \mathrm{fmp}$ & Metal products \\
\hline $32 \mathrm{omf}$ & Manufactures nec \\
\hline 33 ppp & Paper prod., publishing \\
\hline $34 \mathrm{pac}$ & Petroleum, coal prod. \\
\hline $35 \mathrm{crp}$ & Chem., rubber \\
\hline $36 \mathrm{mvh}$ & Motor vehicles and parts \\
\hline 37 otn & Transport equipment nec \\
\hline 38 ele & Electronic equipment \\
\hline 39 ome & Mach'y \& equip't nec \\
\hline 41 Ser & Services \\
\hline
\end{tabular}

\begin{tabular}{|c|c|c|c|c|}
\hline \multirow[b]{2}{*}{ Initial } & \multicolumn{4}{|c|}{ Scenario } \\
\hline & (a) & (b) & (c) & (d) \\
\hline 0,12 & 0,08 & 0,08 & 0,08 & 0,09 \\
\hline 0,16 & 0,11 & 0,12 & 0,10 & 0,13 \\
\hline 0,32 & 0,21 & 0,26 & 0,20 & 0,24 \\
\hline 0,13 & 0,09 & 0,09 & 0,08 & 0,10 \\
\hline 0,04 & 0,03 & 0,03 & 0,03 & 0,03 \\
\hline 0,03 & 0,02 & 0,02 & 0,02 & 0,03 \\
\hline 0,15 & 0,10 & 0,10 & 0,10 & 0,12 \\
\hline 0,35 & 0,22 & 0,33 & 0,20 & 0,25 \\
\hline 0,05 & 0,03 & 0,03 & 0,03 & 0,04 \\
\hline 0,09 & 0,06 & 0,06 & 0,06 & 0,06 \\
\hline 0,23 & 0,15 & 0,19 & 0,12 & 0,15 \\
\hline 0,31 & 0,20 & 0,27 & 0,17 & 0,22 \\
\hline 0,12 & 0,08 & 0,09 & 0,08 & 0,09 \\
\hline 0,35 & 0,23 & 0,28 & 0,21 & 0,26 \\
\hline 0,12 & 0,08 & 0,08 & 0,07 & 0,09 \\
\hline 0,34 & 0,22 & 0,27 & 0,21 & 0,26 \\
\hline 0,09 & 0,06 & 0,06 & 0,06 & 0,07 \\
\hline 0,26 & 0,17 & 0,20 & 0,15 & 0,17 \\
\hline 0,02 & 0,01 & 0,01 & 0,01 & 0,01 \\
\hline 0,01 & 0,01 & 0,01 & 0,01 & 0,01 \\
\hline 0,04 & 0,02 & 0,02 & 0,02 & 0,03 \\
\hline 0,03 & 0,02 & 0,02 & 0,02 & 0,02 \\
\hline 0,07 & 0,04 & 0,05 & 0,04 & 0,05 \\
\hline 0,04 & 0,02 & 0,03 & 0,02 & 0,03 \\
\hline 0,09 & 0,06 & 0,08 & 0,04 & 0,05 \\
\hline 0,11 & 0,07 & 0,10 & 0,03 & 0,04 \\
\hline 0,13 & 0,08 & 0,12 & 0,04 & 0,05 \\
\hline 0,04 & 0,02 & 0,03 & 0,02 & 0,03 \\
\hline 0,07 & 0,05 & 0,06 & 0,04 & 0,05 \\
\hline 0,08 & 0,06 & 0,07 & 0,05 & 0,06 \\
\hline 0,07 & 0,05 & 0,07 & 0,03 & 0,04 \\
\hline 0,04 & 0,03 & 0,03 & 0,03 & 0,03 \\
\hline 0,02 & 0,01 & 0,02 & 0,01 & 0,02 \\
\hline 0,06 & 0,04 & 0,04 & 0,04 & 0,04 \\
\hline 0,07 & 0,05 & 0,07 & 0,04 & 0,05 \\
\hline 0,03 & 0,02 & 0,02 & 0,02 & 0,02 \\
\hline 0,06 & 0,04 & 0,04 & 0,04 & 0,04 \\
\hline 0,07 & 0,04 & 0,06 & 0,04 & 0,05 \\
\hline 0,01 & 0,00 & 0,01 & 0,01 & 0,01 \\
\hline
\end{tabular}

Unweighted std-dev of AVE tariffs across partners

\begin{tabular}{ccccc}
\hline & \multicolumn{4}{c}{ Scenario } \\
\cline { 2 - 5 } Initial & $(\mathrm{a})$ & (b) & (c) & (d) \\
0,04 & 0,06 & 0,06 & 0,06 & 0,04 \\
0,06 & 0,08 & 0,07 & 0,08 & 0,07 \\
0,15 & 0,17 & 0,15 & 0,18 & 0,16 \\
0,07 & 0,09 & 0,08 & 0,09 & 0,08 \\
0,04 & 0,05 & 0,05 & 0,05 & 0,04 \\
0,05 & 0,05 & 0,05 & 0,05 & 0,05 \\
0,03 & 0,06 & 0,05 & 0,06 & 0,04 \\
0,25 & 0,28 & 0,25 & 0,30 & 0,27 \\
0,01 & 0,02 & 0,02 & 0,02 & 0,02 \\
0,05 & 0,06 & 0,06 & 0,06 & 0,05 \\
0,11 & 0,14 & 0,12 & 0,16 & 0,14 \\
0,10 & 0,15 & 0,11 & 0,17 & 0,14 \\
0,03 & 0,05 & 0,04 & 0,05 & 0,04 \\
0,10 & 0,16 & 0,13 & 0,17 & 0,13 \\
0,04 & 0,05 & 0,05 & 0,06 & 0,05 \\
0,09 & 0,16 & 0,11 & 0,17 & 0,13 \\
0,03 & 0,05 & 0,05 & 0,05 & 0,04 \\
0,08 & 0,12 & 0,10 & 0,13 & 0,12 \\
0,01 & 0,01 & 0,01 & 0,01 & 0,01 \\
0,01 & 0,01 & 0,01 & 0,01 & 0,01 \\
0,02 & 0,03 & 0,03 & 0,03 & 0,03 \\
0,01 & 0,02 & 0,02 & 0,02 & 0,02 \\
0,02 & 0,03 & 0,02 & 0,03 & 0,02 \\
0,02 & 0,02 & 0,02 & 0,02 & 0,02 \\
0,04 & 0,05 & 0,04 & 0,06 & 0,05 \\
0,07 & 0,07 & 0,07 & 0,09 & 0,08 \\
0,06 & 0,07 & 0,06 & 0,09 & 0,08 \\
0,02 & 0,03 & 0,03 & 0,03 & 0,03 \\
0,02 & 0,03 & 0,02 & 0,04 & 0,03 \\
0,04 & 0,06 & 0,05 & 0,07 & 0,06 \\
0,04 & 0,05 & 0,04 & 0,06 & 0,05 \\
0,02 & 0,03 & 0,03 & 0,03 & 0,03 \\
0,01 & 0,02 & 0,01 & 0,02 & 0,01 \\
0,01 & 0,03 & 0,02 & 0,03 & 0,02 \\
0,03 & 0,04 & 0,03 & 0,05 & 0,04 \\
0,03 & 0,04 & 0,03 & 0,04 & 0,04 \\
0,03 & 0,03 & 0,02 & 0,03 & 0,02 \\
& 0,03 & 0,02 & 0,03 & 0,02 \\
0,03 & 0,03 & 0,03 & 0,03
\end{tabular}

Source: MAcMaps, authors' calculations. 



\section{ANNEX 2: IMPACTS ON TRADE FLOWS}

Table A2.1: Impact on world trade by commodity

\begin{tabular}{|c|c|c|c|c|c|c|}
\hline \multirow[b]{3}{*}{ No. Code } & \multirow[b]{3}{*}{ Description } & \multicolumn{5}{|c|}{ World trade in value by commodity } \\
\hline & & \multirow[b]{2}{*}{ Reference } & \multicolumn{3}{|c|}{ Scenario } & \multirow[b]{2}{*}{ (d) } \\
\hline & & & (a) & (b) & (c) & \\
\hline $1 \mathrm{pdr}$ & Paddy rice & 0.123 & $11 \%$ & $7 \%$ & $17 \%$ & $16 \%$ \\
\hline 2 wht & Wheat & 1.646 & $14 \%$ & $3 \%$ & $17 \%$ & $12 \%$ \\
\hline 3 gro & Cereal grains nec & 1.657 & $9 \%$ & $5 \%$ & $9 \%$ & $6 \%$ \\
\hline 4 vaf & Vegetables, fruit, nuts & 3.689 & $7 \%$ & $5 \%$ & $7 \%$ & $7 \%$ \\
\hline 5 osd & Oil seeds & 1.955 & $7 \%$ & $3 \%$ & $12 \%$ & $10 \%$ \\
\hline $6 \mathrm{cab}$ & Sugar cane, sugar beet & 0.004 & $-7 \%$ & $0 \%$ & $-12 \%$ & $-11 \%$ \\
\hline 7 ocr & Crops nec & 3.912 & $6 \%$ & $6 \%$ & $5 \%$ & $5 \%$ \\
\hline $8 \mathrm{ctl}$ & Cattle & 0.387 & $11 \%$ & $3 \%$ & $14 \%$ & $10 \%$ \\
\hline 9 oap & Animal products nec & 1.359 & $2 \%$ & $2 \%$ & $2 \%$ & $2 \%$ \\
\hline $10 \mathrm{rmk}$ & Raw Milk & 0.017 & $-4 \%$ & $0 \%$ & $-7 \%$ & $-7 \%$ \\
\hline $11 \mathrm{fsh}$ & Fishing & 0.836 & $1 \%$ & $1 \%$ & $2 \%$ & $2 \%$ \\
\hline $12 \mathrm{cmt}$ & Bovine meat products & 1.633 & $15 \%$ & $8 \%$ & $23 \%$ & $21 \%$ \\
\hline $13 \mathrm{omt}$ & Meat products nec & 2.066 & $43 \%$ & $20 \%$ & $57 \%$ & $46 \%$ \\
\hline $14 \mathrm{vol}$ & Vegetable oils and fats & 3.655 & $30 \%$ & $14 \%$ & $37 \%$ & $28 \%$ \\
\hline $15 \mathrm{mil}$ & Dairy products & 1.473 & $85 \%$ & $33 \%$ & $116 \%$ & $96 \%$ \\
\hline $16 \mathrm{pcr}$ & Processed rice & 0.570 & $67 \%$ & $24 \%$ & $126 \%$ & $94 \%$ \\
\hline 17 sgr & Sugar & 1.247 & $71 \%$ & $36 \%$ & $94 \%$ & $71 \%$ \\
\hline 18 ofd & Food products nec & 9.948 & $25 \%$ & $23 \%$ & $25 \%$ & $22 \%$ \\
\hline 19 bat & Bevg. and tob. Prod. & 3.901 & $40 \%$ & $27 \%$ & $49 \%$ & $44 \%$ \\
\hline $20 \mathrm{pfb}$ & Plant-based fibers & 1.161 & $2 \%$ & $1 \%$ & $2 \%$ & $2 \%$ \\
\hline $21 \mathrm{wol}$ & Wool & 0.320 & $3 \%$ & $3 \%$ & $3 \%$ & $3 \%$ \\
\hline 22 forest & Forestry & 1.219 & $1 \%$ & $1 \%$ & $1 \%$ & $1 \%$ \\
\hline 23 prim & Coal, oil, gas, min. nec & 33.323 & $1 \%$ & $0 \%$ & $3 \%$ & $3 \%$ \\
\hline 24 ias & Ferrous metals & 11.484 & $11 \%$ & $7 \%$ & $13 \%$ & $10 \%$ \\
\hline $25 \mathrm{nfm}$ & Metals nec & 13.776 & $6 \%$ & $4 \%$ & $7 \%$ & $5 \%$ \\
\hline 26 tex & Textiles & 16.306 & $20 \%$ & $6 \%$ & $29 \%$ & $23 \%$ \\
\hline 27 wap & Wearing apparel & 13.912 & $18 \%$ & $8 \%$ & $28 \%$ & $24 \%$ \\
\hline 28 lea & Leather products & 7.254 & $15 \%$ & $6 \%$ & $28 \%$ & $24 \%$ \\
\hline 29 lum & Wood products & 8.969 & $6 \%$ & $3 \%$ & $7 \%$ & $5 \%$ \\
\hline $30 \mathrm{nmm}$ & Mineral products nec & 7.723 & $12 \%$ & $7 \%$ & $15 \%$ & $12 \%$ \\
\hline $31 \mathrm{fmp}$ & Metal products & 8.846 & $12 \%$ & $6 \%$ & $18 \%$ & $14 \%$ \\
\hline $32 \mathrm{omf}$ & Manufactures nec & 15.242 & $8 \%$ & $4 \%$ & $13 \%$ & $10 \%$ \\
\hline 33 ppp & Paper prod., publishing & 9.575 & $6 \%$ & $3 \%$ & $7 \%$ & $5 \%$ \\
\hline 34 pac & Petroleum, coal prod. & 9.432 & $12 \%$ & $6 \%$ & $18 \%$ & $15 \%$ \\
\hline $35 \mathrm{crp}$ & Chem., rubber & 44.589 & $9 \%$ & $6 \%$ & $9 \%$ & $7 \%$ \\
\hline $36 \mathrm{mvh}$ & Motor vehicles and parts & 34.356 & $10 \%$ & $5 \%$ & $15 \%$ & $12 \%$ \\
\hline 37 otn & Transport equipment nec & 14.725 & $5 \%$ & $3 \%$ & $6 \%$ & $5 \%$ \\
\hline 38 ele & Electronic equipment & 72.010 & $5 \%$ & $3 \%$ & $6 \%$ & $4 \%$ \\
\hline 39 ome & Mach'y \& equip't nec & 84.027 & $7 \%$ & $4 \%$ & $7 \%$ & $6 \%$ \\
\hline $40 \operatorname{Tr} \mathrm{T}$ & Transport & 37.374 & $0 \%$ & $0 \%$ & $1 \%$ & $1 \%$ \\
\hline 41 Ser & Services & 70.782 & $0 \%$ & $-1 \%$ & $-1 \%$ & $-1 \%$ \\
\hline
\end{tabular}

Source: Authors' simulations using MIRAGE.

Note: The reference is the level, expressed in tens of billions dollars, of world trade in the reference (i.e., without any liberalization), after 14 years. Changes are expressed in percent of this reference value. 
Table A2.2: Most affected sectoral bilateral trade flows

\begin{tabular}{|c|c|c|c|c|}
\hline \multirow[t]{10}{*}{$\operatorname{scen}(a)$} & pcr & EU25 & Japon & $2085 \%$ \\
\hline & pcr & Row & AED & $763 \%$ \\
\hline & omt & AED & Cairns & $636 \%$ \\
\hline & mil & Row & Japon & $506 \%$ \\
\hline & vol & Japon & $\mathrm{ACP}$ & $439 \%$ \\
\hline & mil & EU25 & Japon & $429 \%$ \\
\hline & vol & Japon & Row & $415 \%$ \\
\hline & mil & Japon & EU25 & $406 \%$ \\
\hline & pcr & Row & Japon & $400 \%$ \\
\hline & pcr & $\mathrm{ACP}$ & Japon & $394 \%$ \\
\hline \multirow[t]{10}{*}{ scen (b) } & sgr & Japon & EU25 & $550 \%$ \\
\hline & pcr & Japon & EU25 & $208 \%$ \\
\hline & mil & Japon & EU25 & $191 \%$ \\
\hline & $\operatorname{sgr}$ & Row & USA & $175 \%$ \\
\hline & mil & Japon & USA & $174 \%$ \\
\hline & mil & $\mathrm{ACP}$ & EU25 & $138 \%$ \\
\hline & pcr & Cairns & EU25 & $126 \%$ \\
\hline & mil & $\mathrm{ACP}$ & AED & $122 \%$ \\
\hline & omt & Japon & Cairns & $116 \%$ \\
\hline & ofd & EU25 & Japon & $115 \%$ \\
\hline \multirow[t]{10}{*}{$\operatorname{scen}(\mathrm{c})$} & pcr & Row & Japon & $6445 \%$ \\
\hline & vol & Japon & $\mathrm{ACP}$ & $5750 \%$ \\
\hline & vol & Japon & Row & $5565 \%$ \\
\hline & pcr & EU25 & Japon & $4511 \%$ \\
\hline & vol & Japon & Cairns & $4216 \%$ \\
\hline & vol & Japon & USA & $3721 \%$ \\
\hline & mil & Row & Japon & $3262 \%$ \\
\hline & vol & Japon & EU25 & $3134 \%$ \\
\hline & vol & Japon & AED & $2752 \%$ \\
\hline & $\operatorname{sgr}$ & AED & EU25 & $2664 \%$ \\
\hline \multirow[t]{10}{*}{$\operatorname{scen}(d)$} & pcr & Row & Japon & $5900 \%$ \\
\hline & vol & Japon & $\mathrm{ACP}$ & $4863 \%$ \\
\hline & vol & Japon & Row & $4779 \%$ \\
\hline & pcr & EU25 & Japon & $4456 \%$ \\
\hline & vol & Japon & Cairns & $4190 \%$ \\
\hline & vol & Japon & USA & $3637 \%$ \\
\hline & mil & Row & Japon & $3181 \%$ \\
\hline & vol & Japon & EU25 & $3072 \%$ \\
\hline & vol & Japon & AED & $3045 \%$ \\
\hline & $\operatorname{sgr}$ & AED & EU25 & $2602 \%$ \\
\hline
\end{tabular}




\section{LIST OF WORKING PAPERS RELEASED BY CEPII ${ }^{18}$}

No

2003-11 On the Adequacy of Monetary Arrangements in SubSaharian Africa

2003-10 The Impact of EU Enlargement on Member States: a CGE Approach

2003-09 India in the World Economy: Traditional Specialisations and Technology Niches

2003-08 Imitation Amongst Exchange-Rate Forecasters: Evidence from Survey Data

2003-07 Le Currency Board à travers l'expérience de l'Argentine

2003-06 Trade and Convergence: Revisiting Ben-Davil

2003-05 Estimating the Fundamental Equilibrium Exchange Rate of Central and Eastern European Countries the EMU Enlargement Perspective

2003-04 Skills, Technology and Growth is ICT the Key to Success?

2003-03 L'investissement en TIC aux Etats-Unis et dans quelques pays européens

2003-02 Can Business and Social Networks Explain the Border Effect Puzzle?

2003-01 Hyperinflation and the Reconstruction of a National Money: Argentina and Brazil, 1990-2002
Authors

A. Bénassy-Quéré \& M. Coupet

H. Bchir, L. Fontagné \& P. Zanghieri

S. Chauvin \& F. Lemoine

M. Beine, A. Bénassy-Quéré \& H. Colas

S. Chauvin \& P. Villa G. Gaulier

B. Egert \& A. Lahrèche-Révil

J. Melka, L. Nayman, S. Zignago \& N. Mulder

G. Cette \& P.A. Noual P.P. Combes, M. Lafourcade \& T. Mayer J. Sgard

2002-18 Programme de travail du CEPII pour 2003

\footnotetext{
${ }^{18}$ Working papers are circulated free of charge as far as stocks are available; thank you to send your request to CEPII, Sylvie Hurion, 9, rue Georges-Pitard, 75015 Paris, or by fax : (33) 0153685504 or by e-mail Hurion@cepii.fr. Also available on: $\backslash$ www.cepii.fr. Working papers with $*$ are out of print. They can nevertheless be consulted and downloaded from this website. 18

Les documents de travail sont diffusés gratuitement sur demande dans la mesure des stocks disponibles. Merci d'adresser votre demande au CEPII, Sylvie Hurion, 9, rue Georges-Pitard, 75015 Paris, ou par fax : (33) 0153685504 ou par e-mail Hurion@cepii.fr. Egalement disponibles sur : \lwww.cepii.fr. Les documents de travail comportant* sont épuisés. Ils sont toutefois consultable sur le web CEPII.
} 
2002-17 MIRAGE, a Computable General Equilibrium Model for Trade Policy Analysis

2002-16 Evolutions démographiques et marché du travail : des liens complexes et parfois contradictoires

2002-15 Exchange Rate Regimes and Sustainable Parities for CEECs in the Run-up to EMU Membership

2002-14 When are Structural Deficits Good Policies?

2002-13 Projections démographiques de quelques pays de l'Union Européenne (Allemagne, France, Italie, Royaume-Uni, Pays-Bas, Suède)

2002-12 Regional Trade Integration in Southern Africa

2002-11 Demographic Evolutions and Unemployment: an Analysis of French Labour Market with Workers Generations

2002-10 Liquidité et passage de la valeur

2002-09 Le concept de coût d'usage Putty-Clay des biens durables

2002-08 Mondialisation et régionalisation : le cas des industries du textile et de l'habillement

2002-07 The Survival of Intermediate Exchange Rate Regimes

2002-06 Pensions and Savings in a Monetary Union: An Analysis of Capital Flow

2002-05 Brazil and Mexico's Manufacturing Performance in International Perspective, 1970-1999

2002-04 The Impact of Central Bank Intervention on Exchange-Rate Forecast Heterogeneity

2002-03 Impacts économiques et sociaux de l'élargissement pour l'Union européenne et la France

2002-02 China in the International Segmentation of Production Processes
M.H. Bchir,

Y. Decreux,

J.L. Guérin \& S. Jean

L. Cadiou, J. Genet \&

J.L. Guérin

V. Coudert \&

C. Couharde

J. Chateau

R. Sleiman

S. Chauvin \& G. Gaulier

J. Château, J.L. Guérin \& F. Legros

$$
\text { P. Villa }
$$

M.G. Foggea \& P. Villa

M. Fouquin, P. Morand R. Avisse G. Minvielle \& P. Dumont

A. Bénassy-Quéré \& B. Coeuré

A. Jousten \& F. Legros

N. Mulder, S. Montout \& L. Peres Lopes

M. Beine, A. Benassy-Quéré, E. Dauchy \& R. MacDonald

M.H. Bchir \& M. Maurel

F. Lemoine \& D. Ünal-Kesenci 
2002-01 Illusory Border Effects: Distance Mismeasurement Inflates Estimates of Home Bias in Trade

2001-22 Programme de travail du CEPII pour 2002

2001-21 Croissance économique mondiale: un scénario de référence à l'horizon 2030

2001-20 The Fiscal Stabilization Policy under EMU - An Empirical Assessment

2001-19 Direct Foreign Investments and Productivity Growth in Hungarian Firms, 1992-1999

2001-18 Market Access Maps: A Bilateral and Disaggregated Measure of Market Access

2001-17 Macroeconomic Consequences of Pension Reforms in Europe: An Investigation with the INGENUE World Model

2001-16* La productivité des industries méditerranéennes

2001-15 Marmotte: A Multinational Model

2001-14 The French-German Productivity Comparison Revisited: Ten Years After the German Unification

2001-13* The Nature of Specialization Matters for Growth: An Empirical Investigation

2001-12 Forum Economique Franco-Allemand - DeutschFranzösisches Wirtschaftspolitisches Forum, Political Economy of the Nice Treaty: Rebalancing the EU Council and the Future of European Agricultural Policies, $9^{\text {th }}$ meeting, Paris, June $26^{\text {th }} 2001$

2001-11 Sector Sensitivity to Exchange Rate Fluctuations
K Head \& T. Mayer

N. Kousnetzoff

A. Kadareja

J. Sgard

A. Bouët, L. Fontagné, M. Mimouni \& X. Pichot

Equipe Ingénue

A. Chevallier \&

D. Ünal-Kesenci

L. Cadiou, S. Dees,

S. Guichard,

A. Kadareja,

J.P. Laffargue \&

B. Rzepkowski

L. Nayman \&

D. Ünal-Kesenci

I. Bensidoun,

G. Gaulier

\& D. Ünal-Kesenci

M. Fouquin, K. Sekkat, J. Malek Mansour, N. Mulder \& L. Nayman 
2001-10* A First Assessment of Environment-Related Trade Barriers

2001-09 International Trade and Rend Sharing in Developed and Developing Countries

2001-08 Economie de la transition : le dossier

2001-07 Exit Options for Argentina with a Special Focus on Their Impact on External Trade

2001-06 Effet frontière, intégration économique et 'Forteresse Europe'

2001-05 Forum Économique Franco-Allemand - DeutschFranzösisches Wirtschaftspolitisches Forum, The Impact of Eastern Enlargement on EU-Labour Markets and Pensions Reforms between Economic and Political Problems, $8^{\text {th }}$ meeting, Paris, January 16 2001

2001-04 Discrimination commerciale : une mesure à partir des flux bilatéraux

2001-03* Heterogeneous Expectations, Currency Options and the Euro/Dollar Exchange Rate

2001-02 Defining Consumption Behavior in a Multi-Country Model

2001-01 Pouvoir prédictif de la volatilité implicite dans le prix des options de change

2000-22 Forum Economique Franco-Allemand - DeutschFranzösisches Wirtschaftspolitisches Forum, Trade Rules and Global Governance: A long Term Agenda and The Future of Banking in Europe, $7^{\text {th }}$ meeting, Paris, July 3-4 2000

2000-21 The Wage Curve: the Lessons of an Estimation Over a Panel of Countries

2000-20 A Computational General Equilibrium Model with Vintage Capital

2000-19 Consumption Habit and Equity Premium in the G7 Countries

2000-18 Capital Stock and Productivity in French Transport: An International Comparison

2000-17 Programme de travail 2001
L. Fontagné, F. von Kirchbach \& M. Mimouni

L. Fontagné \& D. Mirza

G. Wild

S. Chauvin

T. Mayer

G. Gaulier

B. Rzepkowski

O. Allais, L. Cadiou \& S. Dées

B. Rzepkowski

S. Guichard \& J.P. Laffargue

L. Cadiou, S. Dées \& J.P. Laffargue

O. Allais, L. Cadiou \& S. Dées

B. Chane Kune \& N. Mulder 
2000-16 La gestion des crises de liquidité internationale :

J. Sgard logique de faillite, prêteur en dernier ressort et conditionnalité

2000-15 La mesure des protections commerciales nationales

A. Bouët

2000-14 The Convergence of Automobile Prices in the European Union: An Empirical Analysis for the Period 1993-1999

2000-13* International Trade and Firms' Heterogeneity Under S. Jean Monopolistic Competition

2000-12 Syndrome, miracle, modèle polder et autres

S. Jean spécificités néerlandaises : quels enseignements pour l'emploi en France?

2000-11 FDI and the Opening Up of China's Economy

F. Lemoine

2000-10 Big and Small Currencies: The Regional Connection

2000-09* Structural Changes in Asia And Growth Prospects After the Crisis

G. Gaulier \& S. Haller

A. Bénassy-Quéré \&

B. Coeuré

J.C. Berthélemy \&

S. Chauvin

M. Aglietta

2000-08 The International Monetary Fund and the International Financial Architecture

2000-07 The Effect of International Trade on Labour-Demand Elasticities: Intersectoral Matters

2000-06 Foreign Direct Investment and the Prospects for Tax Co-Ordination in Europe

S. Jean

A. Bénéssy-Quéré, L. Fontagné \& A. Lahrèche-Révil

2000-05 Forum Economique Franco-Allemand - DeutschFranzösisches Wirtschaftspolitisches Forum, Economic Growth in Europe Entering a New Area?/The First Year of EMU, $6^{\text {th }}$ meeting, Bonn, January 17-18, 2000

2000-04* The Expectations of Hong Kong Dollar Devaluation and their Determinants

B. Rzepkowski

2000-03 What Drove Relative Wages in France? Structural Decomposition Analysis in a General Equilibrium Framework, 1970-1992

2000-02 Le passage des retraites de la répartition à la capitalisation obligatoire : des simulations à l'aide d'une maquette

2000-01* Rapport d'activité 1999 
1999-16 Exchange Rate Strategies in the Competition for Attracting FDI

1999-15 Groupe d'échanges et de réflexion sur la Caspienne. Recueil des comptes-rendus de réunion (déc. 97- oct. 98)"

1999-14 The Impact of Foreign Exchange Interventions: New Evidence from FIGARCH Estimations

1999-13 Forum Economique Franco-Allemand - DeutschFranzösisches Wirtschaftspolitisches Forum, Reduction of Working Time/Eastward Enlargment of the European Union, $5^{\text {th }}$ meeting, Paris, July 6-7 1999

1999-12* A Lender of Last Resort for Europe

1999-11* La diversité des marchés du travail en Europe : Quelles conséquences pour l'Union Monétaire ; Deuxième partie : Les implications macroéconomiques de la diversité des marchés du travail

1999-10* La diversité des marchés du travail en Europe : Quelles conséquences pour l'Union Monétaire ; Première partie : La diversité des marchés du travail dans les pays de l'Union Européenne

1999-09 The Role of External Variables in the Chinese Economy; Simulations from a macroeconometric model of China

1999-08 Haute technologie et échelles de qualité : de fortes asymétries en Europe

1999-07 The Role of Capital Accumultion, Adjustment and Structural Change for Economic Take-Off: Empirical Evidence from African Growth Episodes

1999-06 Enterprise Adjustment and the Role of Bank Credit in Russia: Evidence from a 420 Firm's Qualitative Survey

1999-05 Central and Eastern European Countries in the International Division of Labour in Europe

1999-04 Forum Economique Franco-Allemand - Economic Policy Coordination $-4^{\text {th }}$ meeting, Bonn, January 11121999
A. Bénassy-Quéré, L. Fontagné \&

A. Lahrèche-Révil

D. Pianelli \&

G. Sokoloff

M. Beine,

A. Bénassy-Quéré \&

C. Lecourt

M. Aglietta

L. Cadiou, S. Guichard \& M. Maurel

L. Cadiou \&

S. Guichard

S. Dees

L. Fontagné, M. Freudenberg \& D. Ünal-Kesenci

J.C. Berthélemy \&

L. Söderling

S. Brana, M. Maurel \& J. Sgard

M. Freudenberg \& F. Lemoine 
1999-03 Models of Exchange Rate Expectations:

Heterogeneous Evidence From Panel Data

1999-02 Forum Economique Franco-Allemand - Labour Market \& Tax Policy in the EMU

1999-01 Programme de travail 1999
A. Bénassy-Quéré, S. Larribeau \&

R. MacDonald 


\section{CEPII \\ DOCUMENTS DE TRAVAIL / WORKING PAPERS}

Si vous souhaitez recevoir des Documents de travail, merci de remplir le coupon-réponse ci-joint et de le retourner à :

Should you wish to receive copies of the CEPII's Working papers, just fill the reply card and return it to:

Sylvie HURION - Publications

CEPII - 9, rue Georges-Pitard - 75740 Paris - Fax : (33) 1.53.68.55.04

M./Mme / Mr./Mrs

Nom-Prénom / Name-First name

Titre / Title

Service / Department

Organisme / Organisation

Adresse / Address

Ville \& CP / City \& post code

Pays / Country Tél.

Désire recevoir les Document de travail du CEPII ${ }^{\circ}$ :

Wish to receive the CEPII's Working Papers No:

Souhaite être placé sur la liste de diffusion permanente (pour les bibliothèques)

Wish to be placed on the standing mailing list (for Libraries). 